\title{
Article \\ Cardiolipin-Containing Lipid Membranes Attract the Bacterial Cell Division Protein DivIVA
}

\author{
Nad'a Labajová ${ }^{1, *(\mathbb{D}}$, Natalia Baranova ${ }^{2} \mathbb{D}$, Miroslav Jurásek ${ }^{3}$, Robert Vácha ${ }^{3, *}$, Martin Loose ${ }^{2}$ \\ and Imrich Barák $1, *$ (D)
}

1 Institute of Molecular Biology SAS, Dubravska Cesta 21, 84551 Bratislava, Slovakia

2 Institute of Science and Technology Austria (IST Austria), Am Campus 1, 3400 Klosterneuburg, Austria; natalia.baranova@univie.ac.at (N.B.); martin.loose@ist.ac.at (M.L.)

3 CEITEC and Faculty of Science, Masaryk University, Kamenice 5, 62500 Brno, Czech Republic; jurasek.m@gmail.com

* Correspondence: umbinapa@savba.sk (N.L.); robert.vacha@mail.muni.cz (R.V.); imrich.barak@savba.sk (I.B.)

Citation: Labajová, N.; Baranova, N.; Jurásek, M.; Vácha, R.; Loose, M.; Barák, I. Cardiolipin-Containing Lipid Membranes Attract the Bacterial Cell Division Protein DivIVA. Int. J. Mol. Sci. 2021, 22, 8350 https://doi.org/10.3390/ ijms 22158350

Academic Editor: Georg A. Sprenger

Received: 2 July 2021

Accepted: 1 August 2021

Published: 3 August 2021

Publisher's Note: MDPI stays neutral with regard to jurisdictional claims in published maps and institutional affiliations.

Copyright: (c) 2021 by the authors. Licensee MDPI, Basel, Switzerland. This article is an open access article distributed under the terms and conditions of the Creative Commons Attribution (CC BY) license (https:// creativecommons.org/licenses/by/ $4.0 /)$.

\begin{abstract}
DivIVA is a protein initially identified as a spatial regulator of cell division in the model organism Bacillus subtilis, but its homologues are present in many other Gram-positive bacteria, including Clostridia species. Besides its role as topological regulator of the Min system during bacterial cell division, DivIVA is involved in chromosome segregation during sporulation, genetic competence, and cell wall synthesis. DivIVA localizes to regions of high membrane curvature, such as the cell poles and cell division site, where it recruits distinct binding partners. Previously, it was suggested that negative curvature sensing is the main mechanism by which DivIVA binds to these specific regions. Here, we show that Clostridioides difficile DivIVA binds preferably to membranes containing negatively charged phospholipids, especially cardiolipin. Strikingly, we observed that upon binding, DivIVA modifies the lipid distribution and induces changes to lipid bilayers containing cardiolipin. Our observations indicate that DivIVA might play a more complex and so far unknown active role during the formation of the cell division septal membrane.
\end{abstract}

Keywords: Clostridioides difficile; DivIVA; lipid membrane; cardiolipin; phosphatidylglycerol

\section{Introduction}

Clostridioides difficile is a Gram-positive obligate anaerobic bacterium and a primary cause of antibiotic-associated diarrhoea, and a frequent cause of nosocomial infections [1-3]. Its ability to produce toxins and to form spores makes it a highly aggressive and resistant infectious agent. In severe cases, it can even cause death of the infected patients. Worldwide, C. difficile infection rates and related deaths are comparable or even higher than infections and deaths caused by methicillin-resistant Staphylococcus aureus (MRSA) [2-6]. Hence, C. difficile infections cause serious problems and put extensive economic pressure on healthcare systems. The details of the $C$. difficile cell division and sporulation mechanisms and the functioning of the proteins involved in them are of great importance and could allow the development of drugs for disease treatment and preventing its spread.

One of the proteins that plays an important role during both vegetative cell division and asymmetric cell division during sporulation is DivIVA. DivIVA homologues are usually present in Gram-positive bacteria and have been studied for decades, especially in the model organism Bacillus subtilis. DivIVA is a late division protein and appears at the division site slightly later than the early division protein complex, which is led by the key division protein FtsZ [7-9]. DivIVA is localized not only at division site but during most of the cell cycle also at the cell poles, where it serves as a topological specifier for numerous proteins $[10,11]$. Importantly, DivIVA determines the subcellular position of the Min system (MinJ, MinD, and MinC), which is a negative regulator of FtsZ polymerization [12-16]. The Min system effectively blocks the formation of malignant polar septa at the cell poles and of 
additional division septa at areas close to the nascent division septum $[12,17,18]$. In $B$. subtilis, DivIVA is involved not only in cell division during vegetative growth but also in other important cellular processes, including competence or chromosome segregation during sporulation [10,16,19-21]. It is crucial for proper localization of RacA during sporulation [22,23], and Maf and ComN for competence [21,24]. Although B. subtilis DivIVA is not considered essential for vegetative growth, DivIVA mutant strains are filamentous [10,19], and unable to sporulate efficiently $[10,19,25,26]$. In other organisms, like Streptomyces coelicolor, Mycobacterium tuberculosis, Mycobacterium smegmatis, and Corynebacterium glutamicum, DivIVA homologues are essential and possess diverse functions [16,27-29]. For instance, in Streptomyces coelicolor, DivIVA is crucial for apical growth and proper morphogenesis [30].

DivIVA protein is a component of the Min system also in C. difficile, along with MinC, MinD, and MinE homologues. The presence of MinE likely enables oscillation of the C. difficile Min system, a dynamic repositioning of MinCDE proteins from one pole to other [31]. The oscillation of the Min system has been characterized in Escherichia coli and creates a gradient of Min protein complex, with its overall highest concentration at the cell poles and lowest in the middle of the cell [32]. Interestingly, the E. coli Min system can oscillate when replanted into B. subtilis cells [33]. Similarly, oscillation of C. difficile MinD and MinE was observed when expressed heterogeneously in B. subtilis cells [31]. The coinciding presence of DivIVA, and its capability to interact with MinD and to stably localize to division site and persist at the cell poles [34] possibly influences the Min oscillation in C. difficile. Whether and how DivIVA affects the C. difficile Min system dynamics are so far unknown.

The key aspect of DivIVA in all the diverse processes, in which it is involved, is its correct localization. As mentioned above, in B. subtilis, DivIVA is recruited to the division site during the later stages of cell division [7]. Rather than protein-protein interactions, however, a negative membrane curvature was suggested to be the key factor determining the recruitment of DivIVA at the division site $[35,36]$. Negative membrane curvature is found at the cell division site because of the membrane invagination, and also at the cell poles; consequently, these are the sites where DivIVA is usually present [10,11]. Although membrane curvature was suggested to be the crucial factor attracting DivIVA to the division site, recent computer simulations suggested that lipid-specific interactions might be involved in its localization. The N-terminal domain of DivIVA from S. coelicolor exhibited an elevated affinity for anionic phospholipids, particularly cardiolipin [37]. However, this preference has not been experimentally confirmed until now.

In this work, we focused on DivIVA from C. difficile, about which only limited information is available. Our results indicate that DivIVA not only has a higher affinity for anionic phospholipids, especially cardiolipin, but that it is also capable of remodelling the lipid bilayer. Its binding to cardiolipin-containing lipid bilayers probably enhances cardiolipin clustering and induces bilayer deformation. Our findings indicate that DivIVA might not only attract crucial division proteins to the division plane but might play an active role in the shaping or scaffolding of the developing septal membrane during cell division.

\section{Results}

\subsection{DivIVA ${ }_{C d}$ Binds More Efficiently to Cardiolipin-Containing Membranes In Vitro}

The structural similarities between DivIVA from B. subtilis (DivIVA $A_{\mathrm{Bs}}$ ) and C. difficile $\left(\right.$ DivIVA $_{C d}$ ) suggest that DivIVA ${ }_{C d}$, like DivIVA ${ }_{B s}$, can bind to the membrane [35,38]. It is known that the $\mathrm{N}$-terminal domain of DivIVA $\mathrm{Bs}_{\mathrm{s}}$ is involved in its attachment to the membrane $[35,36,38]$. It forms a coiled-coil dimer with crossed loops, which expose a combination of a hydrophobic and one or more positively charged amino acid residues on its surface. The hydrophobic residue is thought to be inserted below the lipid head group and interact with the phospholipid tails, while the positively charged residue(s) (usually arginine) interact with the lipid phosphate groups [37]. These residues are conserved across several species [38]. For instance, DivIVA ${ }_{B s}$ contains phenylalanine and arginine, while DivIVA $_{C d}$ has leucine and arginine (Figure S1). 
To examine the ability of DivIVA ${ }_{C d}$ to bind to lipids, we performed sedimentation assays with DivIVA ${ }_{C d}$ and small unilamellar vesicles (SUVs) (Figure 1A). We tested SUVs composed of 70\% phosphatidylcholine (PC) and 30\% phosphatidylglycerol (PG) (L1: 70\% PC and 30\% PG), a lipid mixture commonly used to mimic bacterial membranes [39,40]. The membrane of $C$. difficile contains, besides PG (23-35\%), a significant amount (12-20\%) of cardiolipin (CL), another negatively charged phospholipid [41]. We therefore studied vesicles containing 5\% (L4: 65\% PC, 30\% PG, and 5\% CL) and 15\% cardiolipin (L6: 55\% PC, $30 \%$ PG, and $15 \%$ CL). We also examined SUVs composed of $100 \%$ PC (L2) to see if DivIVA $_{C d}$ binds to vesicles composed of only neutral lipids.

A

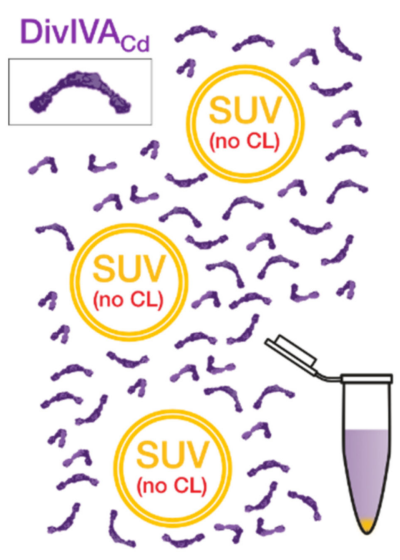

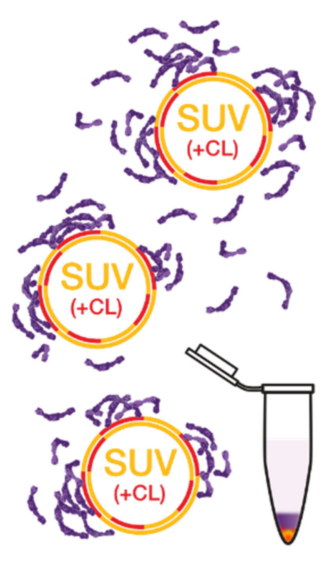

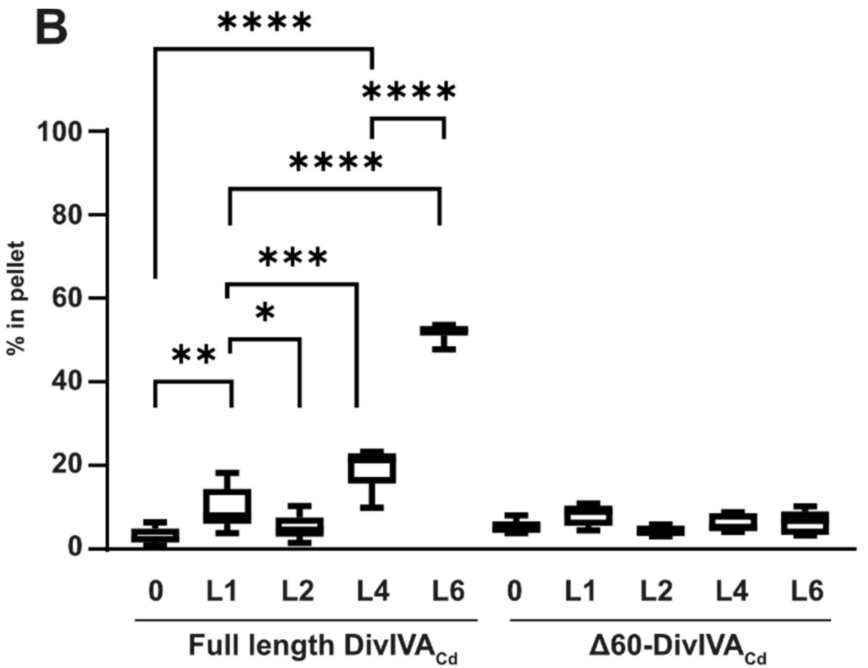

C

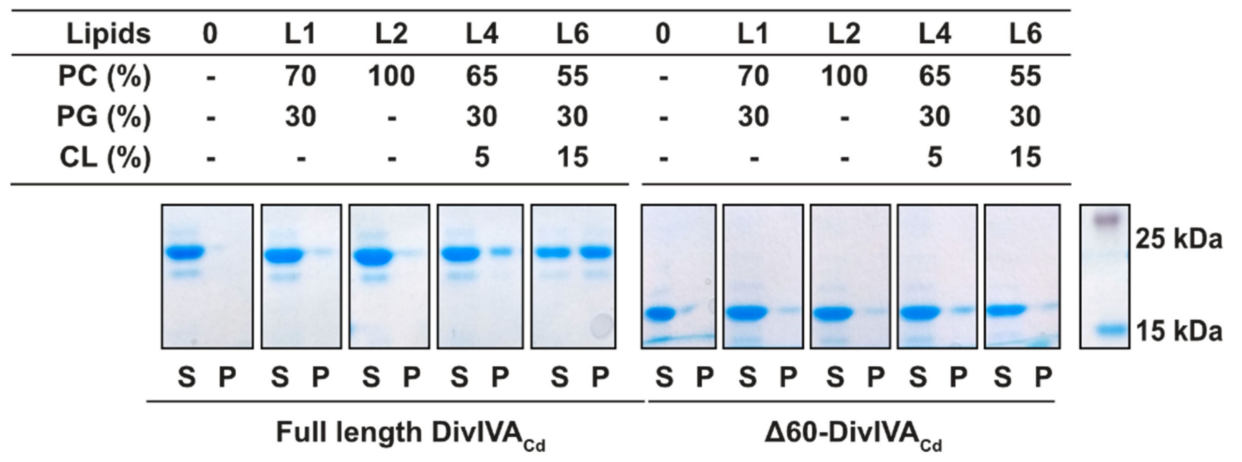

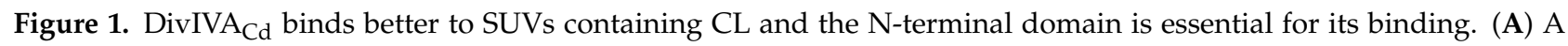
scheme of the sedimentation assay. DivIVA $C$ was mixed with solutions of SUVs that did not contain cardiolipin (in yellow) or contained SUVs with different cardiolipin concentrations (CL is in red). All SUV mixtures were prepared with the buffer containing $30 \%$ sucrose to enhance their sedimentation. The SUVs were pelleted by centrifugation and DivIVA $C$ d amounts were quantified. The DivIVA $\mathrm{Cd}_{\mathrm{i}}$ illustration is based on the structure of the full-length DivIVA $\mathrm{Bs}_{\mathrm{s}}$ tetramer [38]. The sedimentation assay with $\mathrm{N}$-terminally truncated $\Delta 60$-DivIVA $\mathrm{Cd}$ was performed similarly. (B) Box and whisker plots of the percentages of DivIVA ${ }_{C d}$ identified in the pellets under each of the tested conditions. Sedimentation assays were

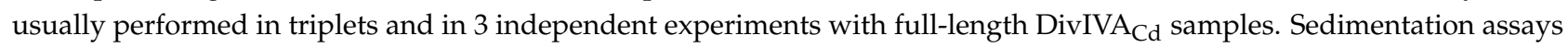
with $\Delta 60$-DivIVA ${ }_{C d}$ were performed in triplets two times. Selected significant $p$-values from two-tailed unpaired $t$-tests are depicted above the plot; the threshold for statistical significance was taken to be $p<0.05$. Stars indicate significantly different values, where ${ }^{*}$ corresponds to $p$-value $\leq 0.05,{ }^{* *}$ to $p \leq 0.01$, $^{* * *}$ to $p \leq 0.001$ and ${ }^{* * *}$ to $p \leq 0.0001$. All $p$-values and percentages of DivIVA ${ }_{C d}$ or $\Delta 60$-DivIVA $C$ in supernatants and pellets are listed in Tables S4-S6. (C) An SDS-PAGE analysis of a representative sedimentation assay. The compositions of the individual SUVs tested are given above the gel. $\mathrm{S}$ refers to the soluble fraction; $\mathrm{P}$, to the pellet. 
In the negative control without SUVs and with L2, similar amounts of DivIVA $\mathrm{Cd}_{\mathrm{C}}$ ( $95 \pm 5 \%$ and $95 \pm 3 \%$, respectively) remained in the soluble fraction (Figure 1B,C). This indicates that DivIVA $\mathrm{Cd}_{\mathrm{d}}$ is not binding to $\mathrm{L} 2$ vesicles in the sedimentation assay. With L1 SUVs, slightly less DivIVA ${ }_{C d}$ was in the soluble fraction $(90 \pm 5 \%)$, which points toward weak binding. Interestingly, cardiolipin-containing vesicles enhanced DivIVA $\mathrm{Cd}$ sedimentation. In the presence of 5\% cardiolipin (L4), $81 \pm 5 \%$ of the DivIVA $\mathrm{Cd}_{\mathrm{d}}$ appeared in the soluble fraction and $19 \%$ of the DivIVA ${ }_{C d}$ was in the pellet (Figure $1 B, C$ ). The effect was even more pronounced in the presence of $15 \%$ cardiolipin (L6): $52 \pm 7 \%$ of the DivIVA $\mathrm{Cd}$ was soluble and $48 \%$ of the DivIVA ${ }_{C d}$ bound to SUVs (Figure 1B,C). The differences between the binding of DivIVA ${ }_{\mathrm{Cd}}$ to the L1, L4, and L6 vesicles are all statistically significant (Table S4), indicating that DivIVA $\mathrm{Cd}_{\mathrm{d}}$ has a preference for cardiolipin.

To test whether the N-terminal domain of DivIVA ${ }_{C d}$ is essential for its binding to the membrane, we prepared an N-terminally truncated DivIVA ${ }_{\mathrm{Cd}}$ protein, lacking the first 60 amino acids ( $\triangle 60$-DivIVA ${ }_{C d}$ ). We could not detect statistically significant differences between the amount of $\triangle 60$-DivIVA ${ }_{C d}$ in the pellet without SUVs and in the presence of the L1, L2, L4, and L6 lipid mixtures (Figure 1B,C, Table S5). Without its N-terminal domain, DivIVA $_{C d}$ lost its ability to bind even to cardiolipin-containing vesicles, confirming that the N-terminal domain is involved in DivIVA ${ }_{C d}$ membrane binding.

\subsection{DivIVA ${ }_{C d}$ Binds to a Supported Lipid Bilayer}

To confirm the preferential binding of DivIVA ${ }_{C d}$ to cardiolipin-containing membranes, we employed a quartz crystal microbalance with dissipation (QCM-D). QCM-D is an acoustic method, which monitors changes in frequency and dissipation after the binding of a macromolecule to a defined substrate layer on a QCM-D sensor. The adsorption of DivIVA $_{C d}$ to a supported lipid bilayer should produce negative frequency $(\Delta f)$ and positive dissipation $(\Delta \mathrm{D})$ shifts (Figure 2A). The changes in frequency and dissipation depend on both the adsorbed mass and the mechanical properties and morphological features of the biomolecular film [42-44].

Using this method, we analysed how DivIVA ${ }_{C d}$ lipid binding depends on the concentrations of both cardiolipin and DivIVA ${ }_{C d}$. We tested mixtures containing either no CL (L1) or $2.5 \%$ CL (L3), $5 \%$ CL (L4), and 7.5\% CL (L5). Unfortunately, formation of a homogenous bilayer on the sensor chip using lipid mixtures with CL concentrations above $7.5 \%$ was not possible, so we could not test the $15 \%$ CL composition (L6) used in the sedimentation assay. We note that other researchers have encountered similar difficulties forming a contiguous SLB on sensor chips with higher cardiolipin concentrations [45].

After forming the lipid bilayers from lipid mixtures L1, L3, L4, or L5, washing with buffer, and obtaining a stable base line, DivIVA ${ }_{C d}$ was added and its concentration stepwise increased from $0.25 \mu \mathrm{M}$ to $3.0 \mu \mathrm{M}$. On SLBs consisting of 70\% PC and 30\% PG (L1), the addition of DivIVA $\mathrm{Cd}_{\text {d }}$ produced the highest $\Delta \mathrm{f}$ response of $-18.2 \pm 1.3 \mathrm{~Hz}$ with $3.0 \mu \mathrm{M}$ DivIVA $_{C d}$ at overtones $3,5,7$, and 9 (Figure 2B). The presence of $2.5 \%, 5 \%$, and $7.5 \%$ CL (L3, L4, and L5) in the lipid mixtures enhanced the binding of DivIVA $\mathrm{Cd}_{\text {d }}$ (Figure 2C-E).

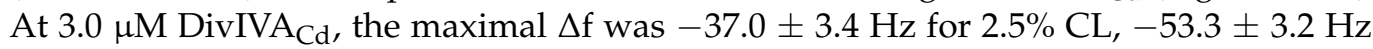
for $5 \% \mathrm{CL}$, and $-71.0 \pm 5.1 \mathrm{~Hz}$ for $7.5 \% \mathrm{CL}$. The preference of DivIVA $\mathrm{Cd}$ for cardiolipincontaining SLBs is visible from a summary plot showing the maximum frequency changes with increasing protein concentration (Figure 2F). The binding is non-linear and the Hill equation can be fitted well to the data. Without cardiolipin, the Hill coefficient is 0.4 , with $2.5 \%$ CL $0.7,5 \%$ CL 1.0, and with 7.5\% CL 1.6, which suggests that DivIVA ${ }_{C d}$ binding is enhanced at higher CL concentrations and is positively cooperative. $\mathrm{K}_{\mathrm{D}}$ was calculated to be in the micromolar range $(5.7 \mu \mathrm{M}$ at $2.5 \% \mathrm{CL}, 1.3 \mu \mathrm{M}$ at $5 \% \mathrm{CL}$, and $0.8 \mu \mathrm{M}$ at $7.5 \%$ $\mathrm{CL}$ ). We also tested the $\mathrm{N}$-terminal truncated $\triangle 60$-DivIVA $\mathrm{Cd}_{\mathrm{d}}$ construct and measured its binding to the L1 and L4 lipid mixtures (Figure S3). The addition of $\triangle 60$-DivIVA ${ }_{C d}$ to these SLBs resulted in a negligible $\Delta \mathrm{f}$ response even after a protein concentration increase up to $2.0 \mu \mathrm{M}$ (Figure S3). 
A

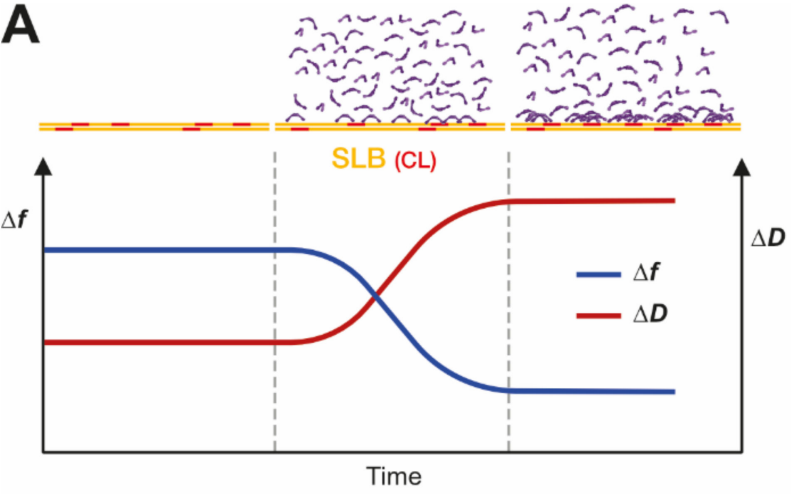

C

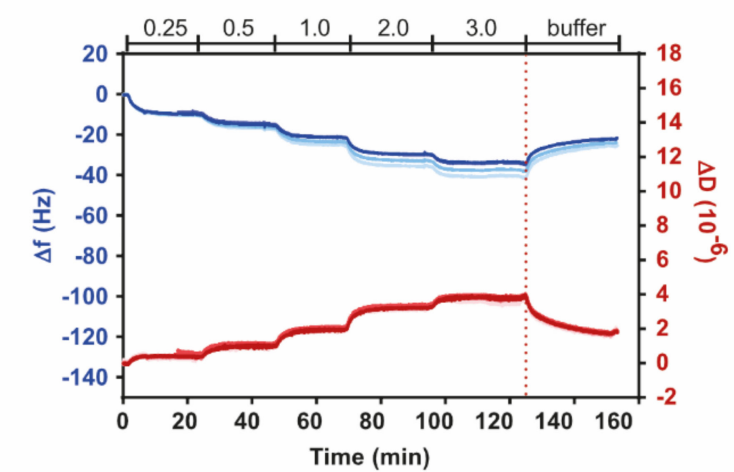

E

L5: $62.5 \% P C+30 \% P G+7.5 \% C L$

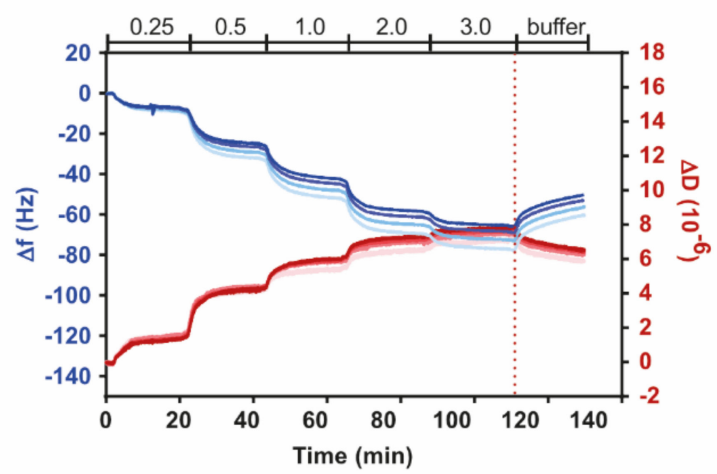

B

L1: $70 \% P C+30 \% P G$

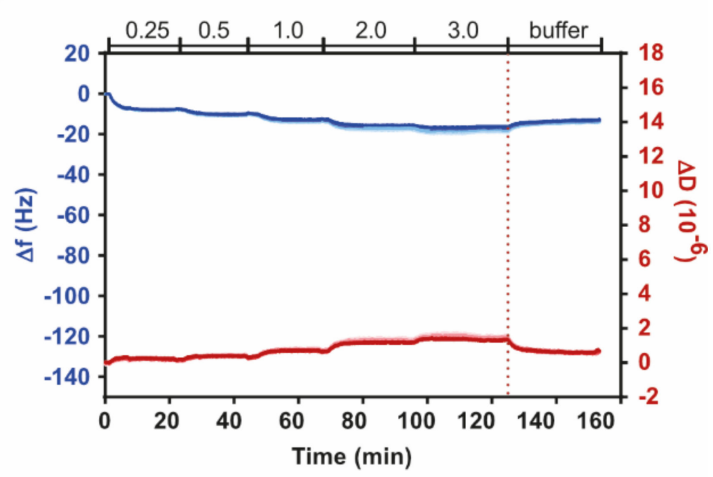

D
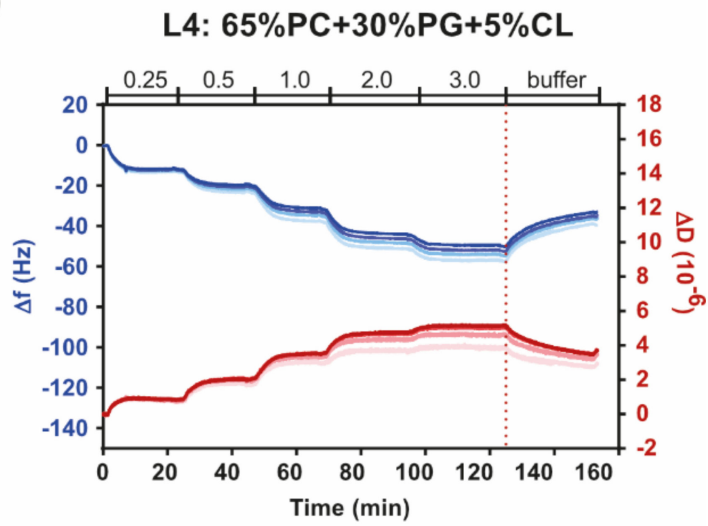

$\mathbf{F}$

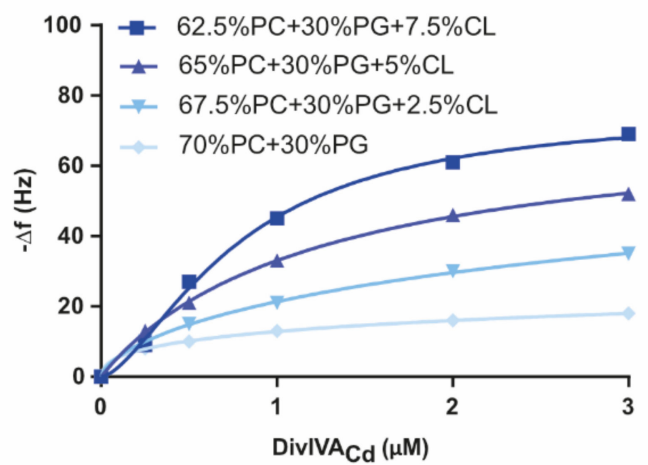

Figure 2. QCM-D measurements confirm that DivIVA ${ }_{C d}$ binding depends on the lipid composition. (A) Simplified scheme of the QCM-D experiment. Full-length DivIVA ${ }_{C d}$ (violet) was layered over the SLB on the QCM-D sensor chip. While the sedimentation assay investigated the binding of DivIVA $\mathrm{Cd}_{\text {do }}$ to vesicles of different lipid composition, this experiment

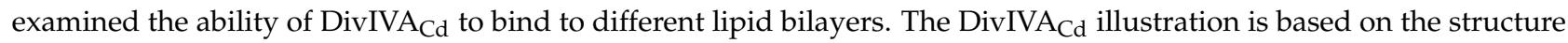
of the full-length DivIVA ${ }_{B s}$ tetramer [38]. The illustration was adapted from biolinscientific.com. (B-E) Results from measurements using supported lipid bilayers (SLBs) containing different cardiolipin concentrations. Layers were formed on a silicon dioxide-coated surface of a quartz crystal from a suspension of liposomes. DivIVA $\mathrm{Cd}$ was added to the SLB

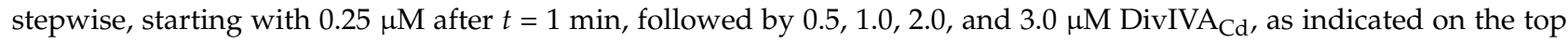
margin of each plot, and the frequency $(\Delta \mathrm{f})$ and dissipation $(\Delta \mathrm{D})$ changes were measured. The plots show $\Delta \mathrm{f}$ (in blue) and $\Delta \mathrm{D}$ (in red) of the third, fifth, seventh, and ninth overtones (lower overtones are in lighter shades, the highest overtone is the darkest shade) normalized to the baseline obtained after SLB formation. (F) A summary plot of the normalized $\Delta \mathrm{f} 7$ versus DivIVA $_{C d}$ concentration shows a clear preference of DivIVA ${ }_{C d}$ for the SLB with CL. The $\Delta \mathrm{f} 7$ curve is reversed, meaning that the ascending curve indicates increased mass absorption. The series were fit non-linearly to the Hill equation. 
The advantage of the QCM-D measurements is that it allows estimation of the viscoelastic properties of the biofilm, i.e., lipid membrane and adsorbed protein, according to the behaviour of different overtones [44,46,47]. In the presence of an SLB that does not contain CL (L1), the $\triangle \mathrm{D}$ between different overtones overlap after DivIVA $\mathrm{Cd}_{\text {addition }}$ (Figure 2B and Figure S2A), which suggests that the biofilm is rigid and homogeneous. At 2.5\% CL (L3, Figure 2C and Figure S2B), 5\% CL (L4, Figure 2D and Figure S2C), and 7.5\% CL (L5, Figure 2E and Figure S2D), the different overtones do not overlap and are nonlinear, which means that the biofilm is soft and is not homogenous. After buffer wash and a partial DivIVA $_{C d}$ detachment, the dissipation shift spread between different overtones persists. Possibly the film remains soft, and DivIVA ${ }_{C d}$ forms stable complexes on the bilayer or it causes irreversible changes to the morphology of the bilayer, or both. Because of the softness and heterogeneity of the biofilm, we did not attempt to estimate the mass and thickness of the adhering DivIVA Cd $_{\text {. }}$

In summary, our measurements demonstrated that DivIVA $\mathrm{Cd}_{\mathrm{d}}$ is capable of binding to liposomes and to SLBs. Its binding is strongly dependent on the lipid composition and cardiolipin enhances it. Low but measurable binding of DivIVA Cd $_{\text {do }} 30 \%$ PG-containing membranes (L1), especially in the QCM-D assay, indicates that the plausible molecular

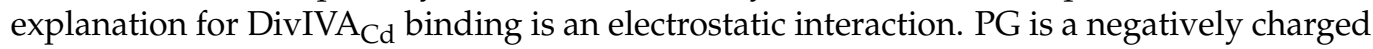
phospholipid with a net charge of -1 at $\mathrm{pH} 7.4$, while CL, or diphosphatidylglycerol, bears a -2 net charge at the same $\mathrm{pH}$. The $\mathrm{N}$-terminal domains of DivIVA $\mathrm{Cd}$ and other DivIVA homologues contain a number of positively charged amino acids, especially around the $\mathrm{N}$-terminal loop responsible for the membrane interaction. An electrostatic interaction between the positively charged N-terminal DivIVA domain and the negatively charged phospholipids-containing membranes has previously been suggested as the mechanism of DivIVA-membrane contact $[37,38]$. Interestingly, the QCM-D results suggest that DivIVA $\mathrm{Cd}$ induces morphological changes only to SLBs containing cardiolipin. We also confirmed that the N-terminal domain is essential for the DivIVA $\mathrm{Cd}$-lipid interaction.

\subsection{DivIVA ${ }_{C d}$ Deforms the Supported Lipid Bilayer}

The QCM-D measurements of DivIVA ${ }_{C d}$ binding to CL-containing SLBs indicated that DivIVA ${ }_{C d}$ binding might introduce morphological changes to the membrane. To determine the possible changes to the SLB, we examined SLBs with fluorescently labelled lipids using TIRF (total internal reflection fluorescence) microscopy. We analysed the distribution of fluorescently labelled cardiolipin (TopFluor ${ }^{\circledR}$ Cardiolipin, TF-CL) before and after DivIVA ${ }_{C d}$ addition to individual SLBs. Unfortunately, already with SLBs, in which the only cardiolipin present was the $0.1 \%$ TopFluor ${ }^{\circledR}$ Cardiolipin (L1*: $69.9 \%$ PC, $30 \%$ PG and $0.1 \%$ TF-CL), the fluorescent signal was not uniformly distributed before DivIVA $_{\mathrm{Cd}}$ addition (Figure 3A). To some extent, TopFluor ${ }^{\circledR}$ Cardiolipin formed clusters by itself. After DivIVA ${ }_{C d}$ addition, these foci became larger and brighter (Figure 3B) clearly,

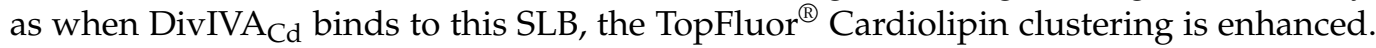
In the presence of 5\% CL (L4*: 64.9\% PC, 30\% PG +5\% CL, and 0.1\% TF-CL), a larger number of small fluorescent foci were present before DivIVA $\mathrm{Cd}_{\mathrm{d}}$ addition (Figure $3 \mathrm{C}$ ), and, after the addition of DivIVA ${ }_{C d}$, even larger clusters than in the sample without cardiolipin became visible (compare Figure 3B,D). To examine the dynamics of the lipids within the SLB, we also performed FRAP experiments both before and after DivIVA Cd $_{\text {addition. We }}$ observed fluorescence recovery in all experiments, indicating that the CL clusters are not static assemblies and that DivIVA $\mathrm{Cd}_{\mathrm{d}}$ binding does not prohibit the exchange of lipids within the clusters (Figure S4). 

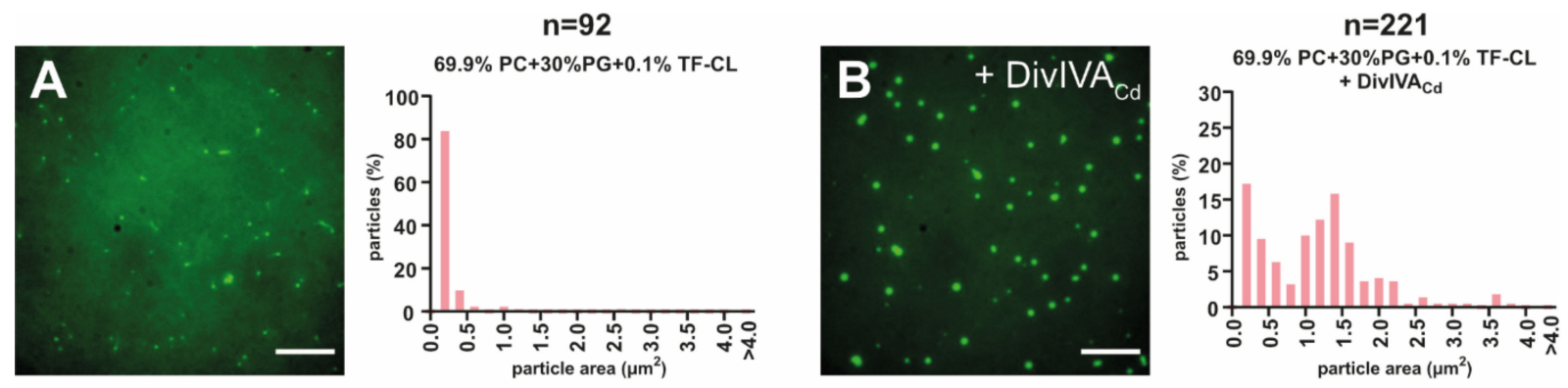

\section{L1*: $69.9 \%$ DOPC+30\% DOPG+0.1\% TF-CL}

$n=1437$

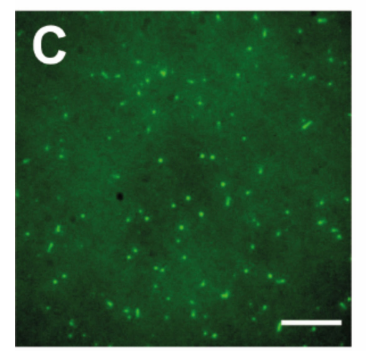

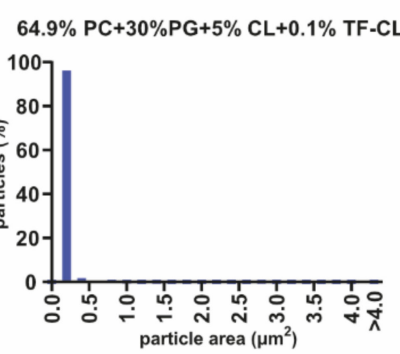
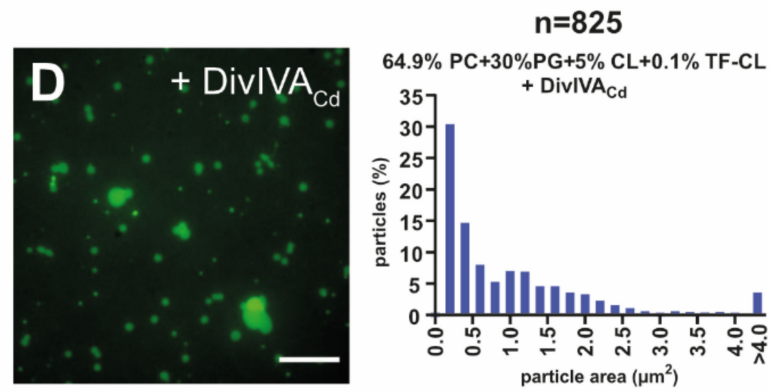

\section{L4*: 64.9\% DOPC+30\% DOPG+5\% TOCL+0.1\% TF-CL}

Figure 3. Changes to SLBs introduced by DivIVA $\mathrm{Cd}$ visualized using fluorescently labelled cardiolipin. (A) Representative image of SLB composed of $69.9 \%$ PC, 30\%, PG and 0.1\% TF-CL (L1*, the asterisk designates the presence of fluorescent TopFluor $^{\circledR}$ Cardiolipin) before the addition of DivIVA ${ }_{C d}$. Most of the fluorescent signal was homogenously distributed, with only few brighter foci of TF-CL visible. (B) The addition of $2 \mu \mathrm{M}$ DivIVA $\mathrm{Cd}$ to L1* caused changes to the fluorescence distribution, resulting in TF-CL clustering. However, we did not observe clusters with areas larger than $4 \mu \mathrm{m}^{2}$. (C) SLB with $64.9 \%$ PC, 30\% PG, 5\% CL, and 0.1\% TF-CL (L4*) before DivIVA ${ }_{C d}$ addition. (D) Adding DivIVA Cd to the chamber with an L4* SLB changed the lipid distribution and morphology of the bilayer even more visibly and larger clusters or foci can be observed ( $4 \%$ larger than $4 \mu \mathrm{m}^{2}$ ). The scale bars represent $10 \mu \mathrm{m}$. The bar charts show the distribution of fluorescent areas from several images analysed using the built-in "Analyse Particle" plugin for automatic particle counting in Fiji. The number of particles (n) detected and measured is given at the top of each chart.

To avoid the clustering of TopFluor ${ }^{\circledR}$ Cardiolipin, which possibly masks the effect of DivIVA $_{C d}$ on such SLBs, we used another fluorescently labelled lipid, lissamine rhodamine phosphatidylethanolamine (Rh-PE). Phosphatidylethanolamine (PE) is a zwitterion whose head contains a negatively charged phosphate and a positively charged free amine, and also the fluorescent moiety is uncharged at neutral $\mathrm{pH}$ [48], making it unlikely that DivIVA $\mathrm{Cd}$ would be attracted by it. On the other hand, as PE's overall shape is conical, it will be abundant in areas with negative curvature [49]. Thus, if the interaction of DivIVA ${ }_{\mathrm{Cd}}$ with $\mathrm{CL}$ leads to curvature formation, we should also expect to observe the redistribution of Rh-PE fluorescence within the SLBs.

Without DivIVA $_{C d}$ the Rh-PE fluorescent signal was mostly uniform in the SLB; only very faint foci were visible either with or without CL (Figure 4A,C). With SLBs that did not contain CL (L1**: $69.9 \%$ PC, 30\%PG, and $0.1 \%$ Rh-PE), the fluorescence distribution after DivIVA ${ }_{C d}$ addition remained unchanged (Figure $4 B$ ). In an SLB containing 5\% CL (L4*: $64.9 \%$ PC, $30 \%$ PG, $5 \%$ CL, and $0.1 \%$ Rh-PE), the addition of DivIVA ${ }_{C d}$ affected the fluorescence signal distribution substantially (Figure 4D,E). Besides larger round clusters, we also observed a variety of different patterns, reminiscent of membrane vesicles or protrusions (Figure 4E). 

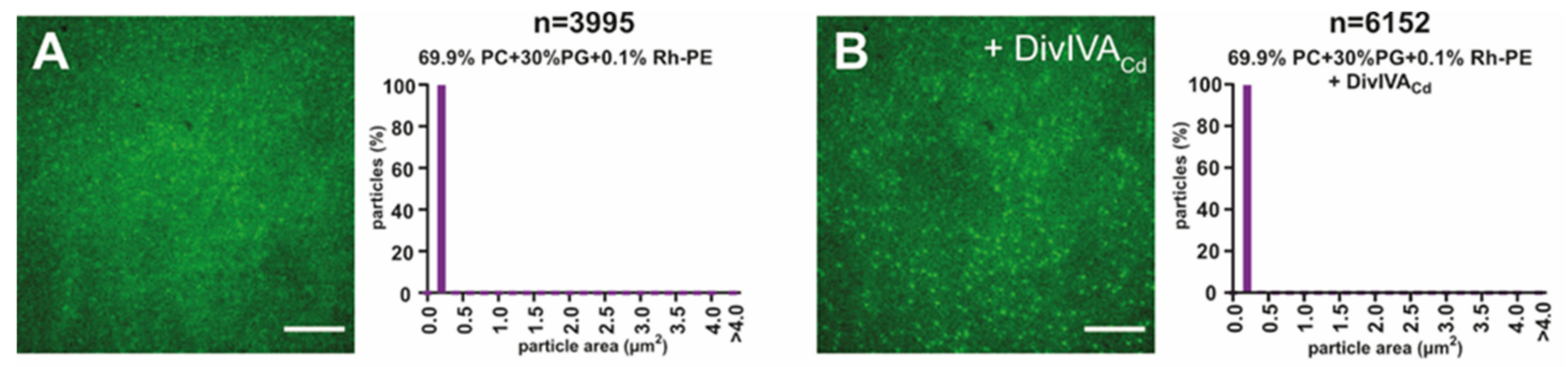

\section{$69.9 \%$ DOPC+30\% DOPG+0.1\% Rh-PE}
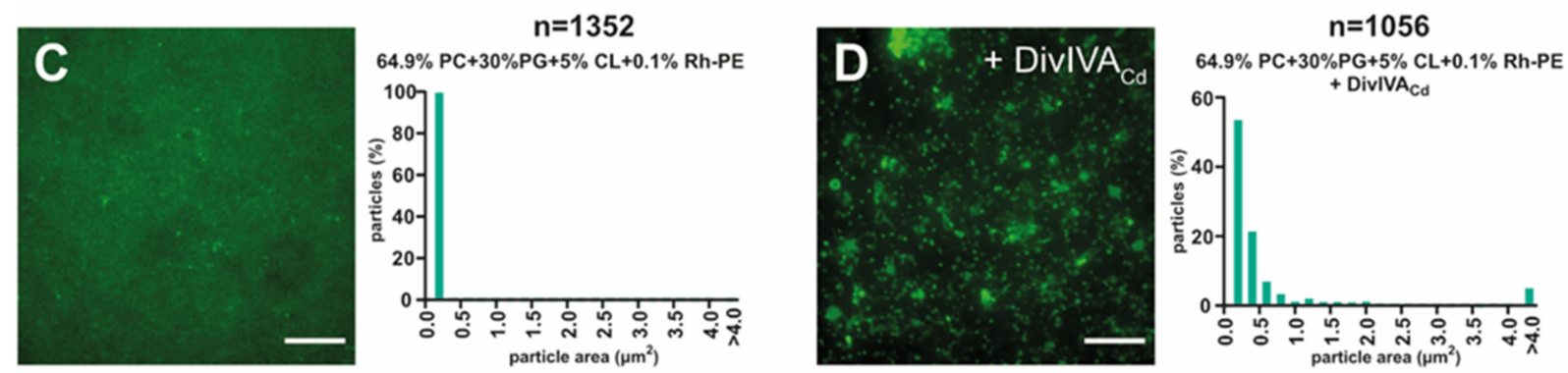

\section{$64.9 \%$ DOPC $+30 \%$ DOPG $+5 \%$ TOCL+0.1\% Rh-PE}
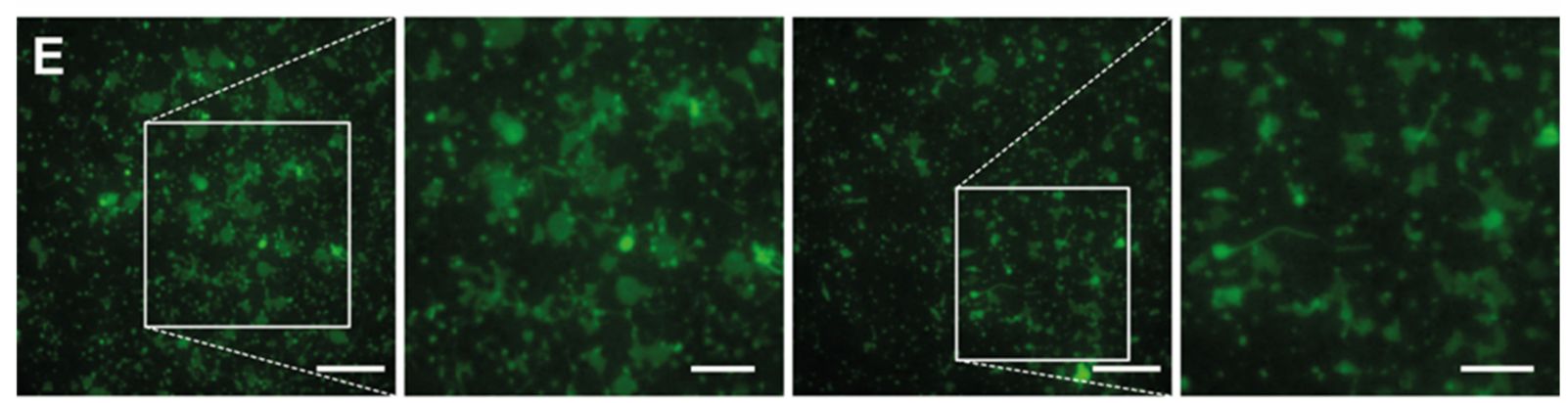

Figure 4. DivIVA $_{C d}$ binding also affects the lipid distribution in SLBs containing cardiolipin and labelled phosphatidylethanolamine. (A) The fluorescence in SLBs composed of $69.9 \%$ PC, 30\% PG, and 0.1\% Rh-PE (L1**) without DivIVA $_{C d}$ was evenly distributed (a double asterisk indicates the presence of fluorescent phosphatidylethanolamine in the lipid mixture designation). (B) In L1** samples, the fluorescence distribution remained unchanged after $2 \mu \mathrm{M}$ DivIVA ${ }_{C d}$ was added. (C) SLB containing 64.9\% PC, 30\% PG, 5\% CL, and 0.1\% Rh-PE (L4**) was also examined before the addition of DivIVA Cd $_{\text {. }}$ (D) The addition of $2 \mu \mathrm{M}_{\text {DivIVA }}$ to SLBs containing $5 \%$ CL caused changes in the lipid distribution and possibly morphological changes to the bilayer. Larger clusters formed, of which some measured several micrometres $(5 \%$ larger than $4 \mathrm{\mu m}^{2}$ ). (E) Details of the L4** bilayer changes observed in the presence of DivIVA ${ }_{\mathrm{Cd}}$. The scale bars represent $10 \mu \mathrm{m}$ in $(\mathbf{A}-\mathbf{E})$ and $5 \mu \mathrm{m}$ in the magnified views.

The TIRF microscopy results show that DivIVA ${ }_{C d}$ rearranges SLBs containing cardiolipin. Most likely, the binding of DivIVA $\mathrm{Cd}$ to the lipid bilayer causes changes in the lipid distribution, the formation of CL clusters, and possibly bilayer deformations. We did not observe changes in the lipid distribution in bilayers without cardiolipin (L1), even though our previous QCM-D data indicate that DivIVA ${ }_{C d}$ does bind to them. 


\subsection{DivIVA Also Shows a Higher Affinity for Cardiolipin-Containing Membranes in Molecular Dynamics Simulations}

To investigate the interaction between the N-terminal domain of DivIVA $\mathrm{Cd}_{\text {and }}$ different lipids at the molecular level, we performed molecular dynamics simulations. First, we prepared a homology model of the N-terminal domain of $C$. difficile DivIVA ${ }_{C d}$ using the DivIVA $_{\mathrm{Bs}} \mathrm{N}$-terminal domain as a template. This modelling indicated that the DivIVA $\mathrm{Cd}$ $\mathrm{N}$-terminal domain has a similar charge distribution as the corresponding domain of B. subtilis DivIVA (Figure 5A). We tested three membrane compositions in the molecular dynamics simulations: 100\% PC (L2), 5\% CL (L4), and 15\% CL (L6). We found that the $\mathrm{N}$-terminal domain interacts with all three membranes (Figure 5B-D), although in one out of the two simulations of the L2 membrane, the domain desorbed from the membrane. This unbinding indicates that the N-terminal domain has a lower affinity for the $100 \%$ PC membrane. In the two membranes with 5\% and 15\% cardiolipin (L4 and L6), the domain remained bound throughout the whole 200 ns simulation, indicating a stable interaction on this time scale. When bound, the domain remained perpendicular to the membrane (Figure 5). Only the tip of the domain (residues 14-18) was inserted into the membrane where two arginine residues interacted with the phosphates of the head groups and two leucine residues were inserted into the hydrophobic core. We also observed that cardiolipin formed clusters (areas of increased average density) around the domain tip, particularly in the membrane with the higher cardiolipin content (L6). In the membrane with the lower cardiolipin content (L4), the clusters were significantly smaller. The size of the clusters might be affected by the length of our simulations, since a lower membrane cardiolipin content decreases the opportunity for clusters to form. In simulations with both $5 \%$ and $15 \%$ cardiolipin (L4 and L6), a tiny increase in the density of phosphatidylglycerol was also observed. Taken together, our simulations suggest that the $\mathrm{N}$-terminal domain has a higher affinity for anionic lipids, particularly cardiolipin, and are in agreement with the in vitro experiments described above. 


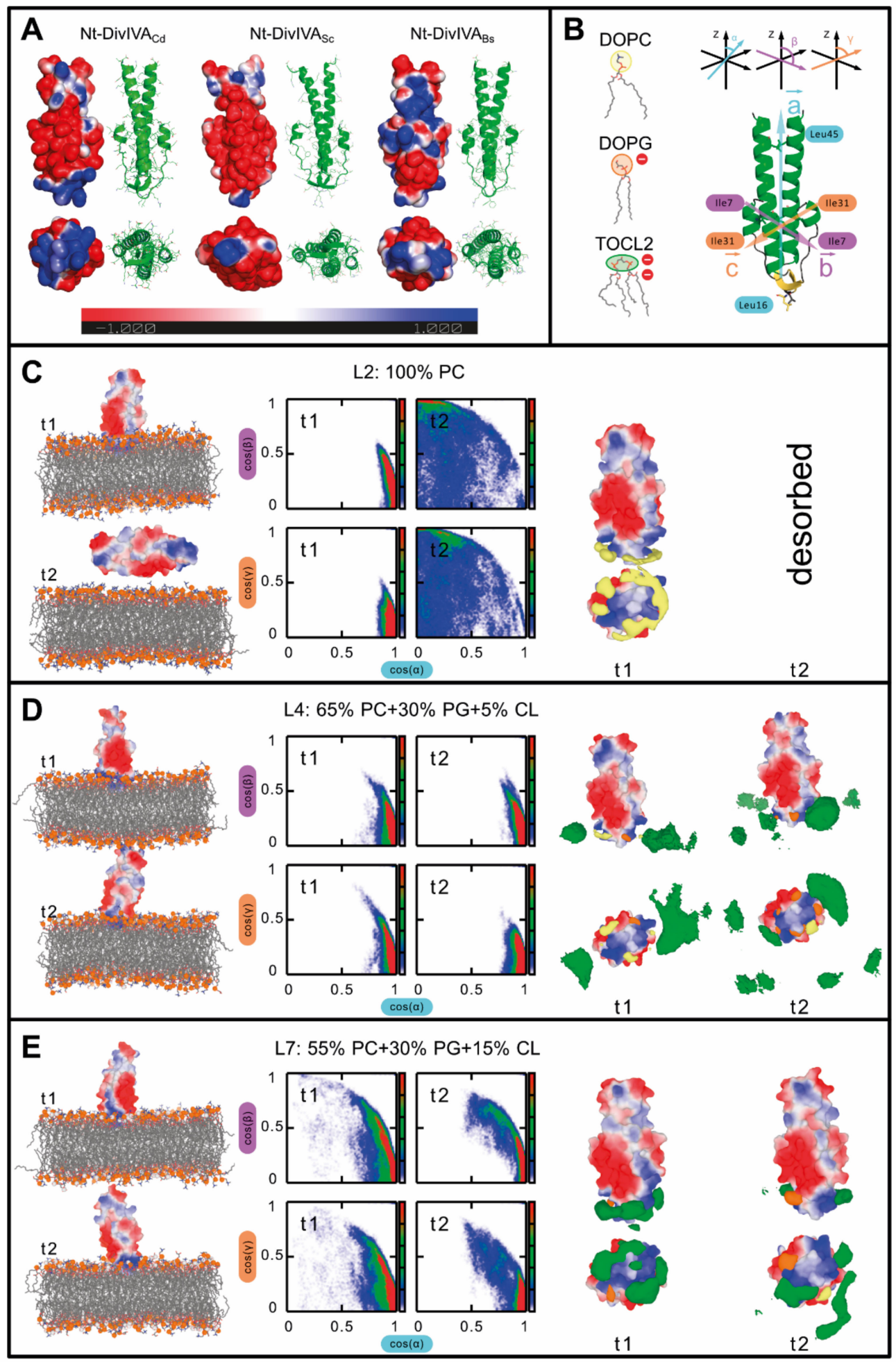

Figure 5. Simulations of the N-terminal domain of DivIVA ${ }_{C d}$ binding to the membrane. (A) A comparison of the N-terminal domain models of $C$. difficile DivIVA $\mathrm{Cd}_{\mathrm{d}}$, S. coelicolor DivIVA $\mathrm{Sc}_{\mathrm{S}}$, and $B$.

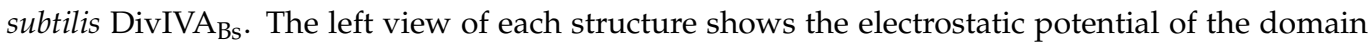
surface (the range is $\pm 1 \mathrm{kT} / \mathrm{e}$, negative is red, positive is blue). The right view shows the domain tertiary structure. The upper views show the side of the domain and the lower views show the view down the membrane-interacting end. (B) On the left are structures of the lipids used in the simulations. Coloured circles around lipid head-groups, with marked negative charges, are used to denote different lipid types in the density maps. On the right side is the DivIVA $\mathrm{Cd}_{\mathrm{N}} \mathrm{N}$-terminal domain with three orthogonal axes defined by vectors $a, b$, and $c$, which were used to describe the 
domain orientation with respect to the membrane. Angle $\alpha$ represents the tilt of the domain long axis, while angles $\beta$ and $\gamma$ capture the orientation of the domain sides. (C-E) Results from molecular dynamics simulations using 100\% PC (L2), (C) $65 \%+30 \%$ PG + 5\% CL (L4), and (D) 55\% + 30\% PG $+15 \%$ CL (L6) bilayers. Each panel shows results from two independent simulation trajectories $\mathrm{t} 1$ and $t 2$. Snapshots of the last frames of each simulation are shown on the left side; the molecular surface domain is shown coloured based on its electrostatic potential; the membrane lipids and phosphates are in grey and orange; water is omitted. The middle panels contain histograms showing the distribution of domain orientations with respect to the membrane, where $\cos (\alpha)=1$ corresponds to a perpendicular orientation. The right-hand side shows the densities of the lipid head-groups around the domain tip.

\section{Discussion}

Although bacterial cells lack membrane compartmentalisation similar to eukaryotic organelles, bacterial proteins and protein complexes are substantially organized within the cell and many localize to specific sites with high precision. To understand the complexity of the most essential cell processes (e.g., cell division), it is crucial to study the mechanisms that determine this precision. For example, numerous membrane-binding proteins, including the DivIVA division proteins, show site-specific binding in vivo $[10,11]$. How these proteins find their specific destinations on the cell membrane, especially the cell poles and the division site, is a question of great interest. Membrane curvature sensing has been proposed to be one possible mechanism used by proteins to localize to specific subcellular positions [50]. It was shown previously that B. subtilis DivIVA can recognize concave (negative) membrane curvature $[35,36]$.

DivIVA homologues can be found in numerous members of the Gram-positive bacterial phylum Firmicutes (e.g., Bacillus sp., Clostridioides sp.) and Actinobacteria (e.g., Streptomyces sp., Mycobacteria sp.), and they perform diverse functions. The complexity of the intracellular environment and the limited research tools complicate the study of the mechanisms responsible for their proper positioning and functioning in vivo, however. In this work, we characterized in vitro DivIVA from the human pathogen C. difficile $\left(\right.$ DivIVA $\left._{C d}\right)$, which has a high degree of similarity to B. subtilis DivIVA (DivIVA ${ }_{B s}$ ). We provide the first detailed study on the interaction between DivIVA ${ }_{C d}$ and lipids combined with molecular dynamics simulations. We show that DivIVA ${ }_{C d}$ binds to SUVs containing cardiolipin more efficiently than to SUVs without cardiolipin. We observed that cardiolipin attracts DivIVA $\mathrm{Cd}_{\mathrm{d}}$ to lipid membranes when formed into the supported lipid bilayers (SLBs) in QCM-D assays.

We also examined the involvement of the DivIVA ${ }_{C d} \mathrm{~N}$-terminal domain in binding to lipids. The 3-D structure of DivIVA ${ }_{C d}$ is not known, but our homology model of the Nterminal domain of DivIVA ${ }_{C d}$ shows it is probably similar in structure and surface charge distribution to the known DivIVA N-terminal domains. Molecular dynamics simulations of its binding to lipid bilayers revealed that the $\mathrm{N}$-terminal domain has an affinity for anionic lipids, particularly cardiolipin. This is in agreement with our in vitro experimental results on full-length and N-terminally truncated DivIVA ${ }_{\mathrm{Cd}}$. In contrast to the strong binding of the full-length protein, we did not detect any binding between the N-terminally truncated DivIVA $_{C d}$ and any SUVs in sedimentation assays, nor to any SLB in QCM-D experiments, including those with cardiolipin.

The preferential binding of DivIVA ${ }_{C d}$ to cardiolipin identified here is also consistent with the available in vivo data from the B. subtilis DivIVA homologue. DivIVA $A_{\mathrm{Bs}}$ initially localizes to the developing division septum in vivo, from which the future pole arises, and remains at the cell poles $[10,11]$. When the septal membrane invaginates during division septum formation, negative curvature forms. Due to its conical shape, cardiolipin accumulates in the parts of the membrane with higher curvature [51], and the accumulation of cardiolipin necessarily enhances curvature formation. Interestingly, the major cardiolipin synthase ClsA also localizes to the membrane at the division site, which suggests that additional cardiolipin is synthesized at the division site [52]. Cardiolipin is probably also 
abundant at the at cell poles, which have an inner negative curvature. In both E. coli and $B$. subtilis, cardiolipin-rich polar domains have been identified by staining the cell with the hydrophobic fluorescent dye 10-N-nonyl acridine orange (NAO) $[53,54]$. Though the use of NAO as a specific dye for visualizing cardiolipin domains has recently been called into question [55], the existence of polar cardiolipin-rich domains has not yet been ruled out, even though their existence at the cell poles is only indirectly indicated. For example, the membranes of minicells, DNA-free cells that form after anomalous polar cell division, are enriched in cardiolipin [56]. In addition, the membranes of spores, differentiated cell types arising from a special type of polar cell division, have a higher cardiolipin content [57]. It is highly probable that if cardiolipin-rich domains exist, they will be present throughout the bacterial kingdom and could possibly serve as recognition and anchoring areas for proteins of different functions, possibly including DivIVA.

According to our results, DivIVA ${ }_{C d}$ not only binds to cardiolipin-containing membranes, but it also possibly changes the morphology of these membranes. Using EM, Lenarcic and co-workers [35] showed previously that the morphology of vesicles was also impaired upon DivIVA ${ }_{B s}$ binding. These findings, together with the presence of DivIVA at the developing division septum site, indicate that DivIVA might have a more important role during cell division than previously thought. It is possible that DivIVA plays an active role in septal membrane formation or may serve as a scaffold during membrane invagination. Some in vivo data are consistent with this hypothesis. Specifically, DivIVA $\mathrm{Bs}$ appears at the division site slightly sooner than the septal membrane [7]. In cultures of synchronised germinating spores, more cells have a DivIVA ${ }_{B s}-$ GFP signal at the mid-cell than a visible septum. Similarly, deconvolution fluorescence microscopic imaging of $B$. subtilis cells showed that part of the cells formed a visible DivIVA ${ }_{B s}$ ring before the septal membrane develops, suggesting that DivIVA $\mathrm{Bs}_{\mathrm{s}}$ localizes to septa at the onset of membrane invagination [11].

Based on our findings, we propose a modified model for the mechanism of specific DivIVA localization. Initially, DivIVA binds preferentially to parts of the membrane where cardiolipin or a locally higher concentration of cardiolipin is present (Figure 6). Upon binding, DivIVA possibly attracts more cardiolipin to these areas and consequently more DivIVA molecules bind. DivIVA binding or cardiolipin accumulation causes re-modelling of the bilayer, leading to the migration of even more cardiolipin to these positions. This positive-feedback mechanism enhances curvature formation, which in turn attracts more DivIVA. Possibly both DivIVA's affinity for cardiolipin and its affinity for negative curvature act together and are responsible for DivIVA's specific cellular localization. DivIVA's membrane remodelling capability and whether it plays some role during the cell division requires further research. 


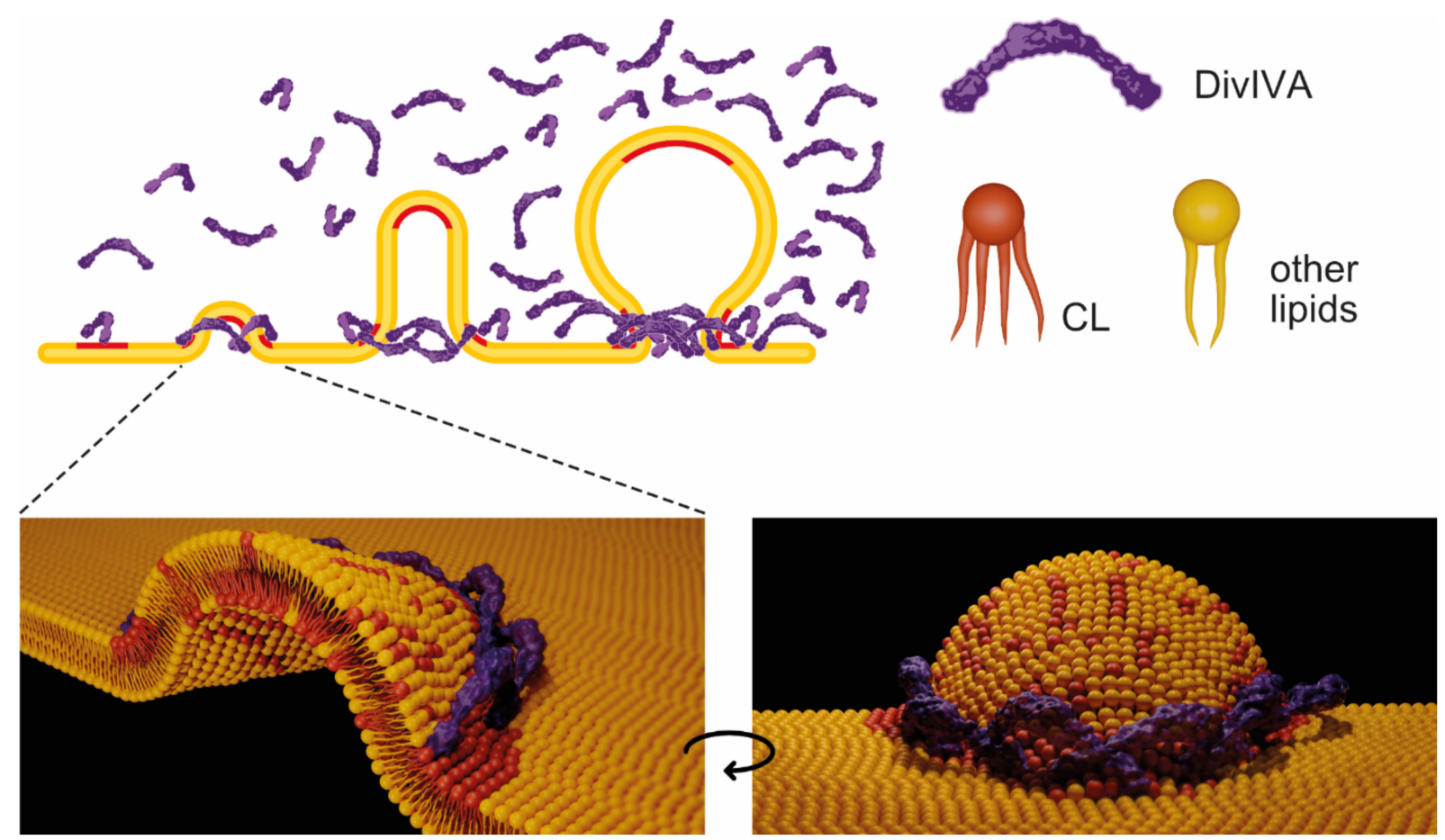

Figure 6. Model of DivIVA ${ }_{C d}$ membrane binding. DivIVA ${ }_{C d}$ preferentially binds to membrane areas with an increased cardiolipin concentration. Bound DivIVA ${ }_{C d}$ attracts more DivIVA ${ }_{C d}$ molecules and cardiolipin to these areas. The bilayer morphology is heavily distorted, and curvature develops. This, in turn, causes more cardiolipin to sort towards these areas and enhance DivIVA ${ }_{C d}$ binding. The DivIVA ${ }_{C d}$ illustration (violet) is based on the structure of the full-length DivIVA $\mathrm{Bs}$ tetramer [38]. This illustration is simplified, however, as the protein forms higher order structures, and the shape and rigidity of these structures are likely to play a role in bilayer shaping. Cardiolipin (CL) is highlighted in red, other lipids are in yellow.

\section{Materials and Methods}

\subsection{General Methods}

For cloning, the E. coli MM294 or E. coli DH5 strains were used and transformations were performed following standard protocols $[58,59]$. The strains were grown in LB medium [60] supplemented with $50 \mu \mathrm{g} / \mathrm{mL}$ kanamycin at $37^{\circ} \mathrm{C}$. A complete list of all E. coli strains and plasmids used in this study is given in Table S1; oligonucleotide primers are given in Table S2. PCR fragments were amplified from the chromosomal DNA of the C. difficile 630 strain (a kind gift from Prof. Neil Fairweather, Imperial College London). DivIVA ${ }_{C d}$ was expressed without tag or as His-SUMO fusion protein. To construct pET26-DivIVA ${ }_{C d}$ (DivIVA $_{C d}$ without tag), the PCR-amplified DivIVA Cd $_{\text {gene, }}$ digested with NdeI/BamHI, was ligated into a pET-26b (Novagen) plasmid cleaved with the same restriction enzymes. The N-terminaly truncated $\Delta 60$-DivIVA ${ }_{C d}$ was prepared in a similar way: a PCR-amplified DivIVA ${ }_{C d}$ gene lacking its first $180 \mathrm{bp}$, digested with NdeI/BamHI, was ligated into a NdeI/BamHI cleaved pET-26b (Novagen) plasmid, giving rise to plasmid pET-26b- $\Delta 60-$ DivIVA $_{C d}$ (Tables $S 1$ and S2). To construct pTB-DivIVA Cd $_{\text {(His- }}$ SUMO-DivIVA $\left._{\mathrm{Cd}}\right)$, the DivIVA ${ }_{\mathrm{Cd}}$ gene was amplified with PCR, cleaved with SapI/BamHI, and ligated into pTB146 [61]. Cloning into SapI site enables expression of fusion protein, which after Ulp1 protease cleavage will not have additional amino acids in comparison to the native protein.

\subsection{DivIVA ${ }_{C d}$ and $\triangle 60-$ DivIVA $A_{C d}$ Protein Expression and Purification}

We used a slightly modified DivIVA Bs $_{\text {p }}$ protein purification protocol [62] for both full-length DivIVA dd $_{\text {and }}$ its truncated version, $\Delta 60$-DivIVA ${ }_{C d}$. For DivIVA Cd $_{\text {and }} \Delta 60-$ DivIVA $_{C d}$ overexpression, E. coli BL21(DE3)pLysS cells containing pET26-DivIVA Cd $_{\text {or }}$ 


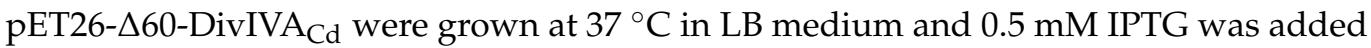
at $\mathrm{OD}_{600} \sim 0.7$. After $3 \mathrm{~h}$ of induction at $37^{\circ} \mathrm{C}$, cells were harvested and stored at $-80^{\circ} \mathrm{C}$ until processed. The cell pellet was thawed and resuspended in buffer A ( $50 \mathrm{mM}$ Tris. $\mathrm{HCl}$, $\mathrm{pH}$ 8.0, $100 \mathrm{mM} \mathrm{NaCl}, 1 \mathrm{mM}$ EDTA) plus cOmplete ${ }^{\mathrm{TM}}$ Protease Inhibitor Cocktail tablets (Roche) and sonicated to lyse the cells. The lysates were centrifuged at $85,000 \times \mathrm{g}$ at $6{ }^{\circ} \mathrm{C}$ for $30 \mathrm{~min}$. DivIVA is a negatively charged protein and forms higher order structures; thus, anion-exchange followed by size exclusion chromatography is used for purification. The supernatants were applied to a HiPrep Q FF 16/10 column (GE Healthcare), washed with 3 column volumes $(\mathrm{CV})$ of buffer $\mathrm{A}$, and eluted using $3 \mathrm{CV}$ of a linear gradient with up to 100\% buffer B (50 mM Tris. $\mathrm{HCl}$, pH 8.0, 1 M NaCl, 1 mM EDTA). DivIVA Cd $_{\text {was }}$ usually found in the $700 \mathrm{mM} \mathrm{NaCl}$ fractions. Selected fractions were pooled, concentrated and loaded onto a Sephacryl 16/60 S-300 HR column (GE Healthcare), and eluted with a buffer composed of $50 \mathrm{mM}$ Tris. $\mathrm{HCl}, \mathrm{pH} 8.0$, and $100 \mathrm{mM} \mathrm{NaCl}$. Most of the DivIVA $\mathrm{Cd}$ eluted in the void volume and in the first third of the column volume, indicating that DivIVA $\mathrm{Cd}_{\mathrm{d}}$ forms large polymers. The best fractions were pooled, concentrated if necessary, aliquoted, and stored at $-80^{\circ} \mathrm{C}$. The N-terminally truncated form of DivIVA ${ }_{C d}\left(\Delta 60\right.$-DivIVA $\left.{ }_{C d}\right)$ was purified in a similar way.

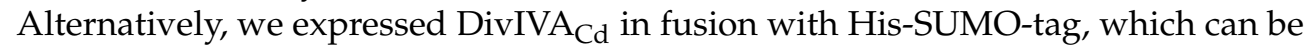
cleaved by His-Ulp1 protease. E. coli BL21(DE3)pLysS cells containing pTB-DivIVA Cd $_{\text {were }}$ grown at $37^{\circ} \mathrm{C}$ in LB medium and $0.5 \mathrm{mM}$ IPTG was added at $\mathrm{OD}_{600} \sim 0.6$. After $1 \mathrm{~h}$ of induction at $30^{\circ} \mathrm{C}$, the temperature was lowered to $18^{\circ} \mathrm{C}$ and culture was grown overnight. Cells were harvested and stored at $-80^{\circ} \mathrm{C}$ until processed. The cell pellet was thawed and resuspended in buffer A (50 mM Tris $\cdot \mathrm{HCl}$, pH 7.5, $150 \mathrm{mM} \mathrm{NaCl}, 50 \mathrm{mM}$ imidazole) plus cOmplete $^{\mathrm{TM}}$ Protease Inhibitor Cocktail tablets (Roche) and sonicated to lyse the cells. The lysates were centrifuged at $85,000 \times g$ at $6{ }^{\circ} \mathrm{C}$ for $30 \mathrm{~min}$. The supernatant was loaded to IMAC Ni-NTA column, extensively washed, and eluted using a $50 \mathrm{mM}-500 \mathrm{mM}$ imidazole linear gradient. The chosen aliquots were pooled and cleaved with in-house prepared His $6_{6}^{-}$ Ulp1 protease overnight at $10{ }^{\circ} \mathrm{C}$. Using PD-10 desalting columns the buffer was changed back to $50 \mathrm{mM}$ Tris. $\mathrm{HCl}, \mathrm{pH} 7.5,150 \mathrm{mM} \mathrm{NaCl}, 50 \mathrm{mM}$ imidazole and samples were re-loaded to the Ni-NTA column. The flow-through fractions contained DivIVA $\mathrm{Cd}_{\text {while }}$ $\mathrm{His}_{6}-\mathrm{SUMO}$ and $\mathrm{His}_{6}$-Ulp1 protease bound to the column. Fractions containing DivIVA $\mathrm{Cd}$ were pooled, and the buffer was changed to $50 \mathrm{mM}$ Tris. $\mathrm{HCl}, \mathrm{pH} 8.0$, and $100 \mathrm{mM} \mathrm{NaCl}$ on PD-10 desalting columns. If necessary, the protein was concentrated, aliquoted, and stored at $-80{ }^{\circ} \mathrm{C}$. This approach yielded purer and more soluble protein. Importantly, the

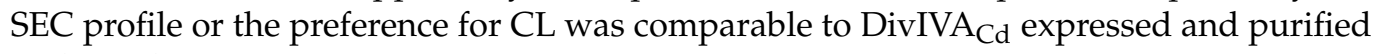
without the tag.

\subsection{Preparation of Small Unilamellar Vesicles (SUVs)}

Different lipid mixtures were used in the assays and were prepared by mixing the synthetic lipids DOPC (1,2-dioleoyl-sn-glycero-3-phosphocholine), DOPG (1,2-dioleoyl-snglycero-3-phospho-rac-1-glycerol), and TOCL (1,3-bis[1,2-dioleoyl-sn-glycero-3-phospho]glycerol), all from Avanti Polar Lipids, Inc. Lipids were solubilised in chloroform and mixed to obtain $5 \mathrm{mM}$ stock solutions as listed in Table S3. The chloroform was evaporated under a stream of nitrogen and the lipids were further vacuum dried for one hour at laboratory temperature. To prepare SUVs for SLB formation, the dried lipid mixtures were hydrated in a buffer containing $25 \mathrm{mM}$ Tris $\cdot \mathrm{HCl}$, pH 7.5, $50 \mathrm{mM} \mathrm{KCl}$, frozen in liquid $\mathrm{N}_{2}$ and thawed 5 times, and tip sonicated with cooling until the solution became translucent. To prepare SUVs for sedimentation assays the dried lipid mixtures were dissolved in a buffer containing $25 \mathrm{mM}$ Tris. $\mathrm{HCl}$, pH 7.5, $50 \mathrm{mM} \mathrm{KCl}$, and 30\% sucrose and the same protocol was followed as above for SUVs without sucrose.

To visualise the lipid bilayer, fluorescent derivatives of phosphatidylethanolamine ((1,2-dioleoyl-sn-glycero-3-phosphoethanolamine-N-(lissamine rhodamine B sulfonyl), Avanti Polar Lipids); Rh-PE) or cardiolipin $\left(\left(1,1^{\prime}, 2,2^{\prime}\right.\right.$-tetraoleoyl cardiolipin[4(dipyrrometheneboron difluoride)butanoyl], Avanti Polar Lipids); TF-CL) were added 
to the lipid mixtures at $0.1 \%$ concentrations and the SUVs were prepared as usual. All fluorescent lipid mixtures are listed in Table S3.

\subsection{Sedimentation Assay}

Prior to each experiment, protein samples were thawed on ice and centrifuged for $10 \mathrm{~min}$ at $16,000 \times g$ to remove potential protein aggregates. A reaction mixture usually contained $5 \mu \mathrm{M}$ DivIVA ${ }_{C d}$ or $10 \mu \mathrm{M} \Delta 60$-DivIVA ${ }_{C d}$ and $1 \mathrm{mM} \mathrm{SUVs}$ and was incubated for $15 \mathrm{~min}$ at $30^{\circ} \mathrm{C}$. Samples were centrifuged for $10 \mathrm{~min}$ at $16,000 \times g$ and $30^{\circ} \mathrm{C}$. Even this low centrifugation force was sufficient to sediment the lipid vesicles to which DivIVA $\mathrm{Cd}_{\mathrm{d}}$ was bound. We also tested higher centrifugation force $(100,000 \times g)$ and obtained similar results (not shown). The supernatant containing the unbound protein fraction was collected and $4 \times$ SDS sample buffer was added to reach a $1 \times$ final concentration. Pellets containing the liposome-bound protein fraction were resuspended directly in $1 \times$ SDS sample buffer. Samples were analysed using SDS-PAGE and the ratio between bound and unbound protein was quantified using the Gel Analysis Fiji plugin. The results were plotted in GraphPad Prism 8 and evaluated using a two-tailed $t$-test. P values were not corrected for multiple comparisons and apply individually to each value, not to the entire family of comparisons.

\subsection{QCM-D Measurements}

To measure the binding of DivIVA ${ }_{C d}$ to SLBs, a QCM-D (QSense Analyzer, Biolin Scientific) was used. The frequency $(\Delta \mathrm{f})$ and dissipation $(\Delta \mathrm{D})$ changes can be obtained from QCM-D by measuring the piezoelectric properties of a quartz sensor upon biomolecule binding [63]. Prior to QCM-D measurements, the silica-coated QCM-D sensors were cleaned in $2 \%$ SDS aqueous solution for $15 \mathrm{~min}$, washed extensively with ultrapure water, and blow-dried. All measurements were performed at $23^{\circ} \mathrm{C}$ at 5 overtones, $n=3,5,7,9$, 11 , corresponding to resonance frequencies of $15,25,35,45$, and $55 \mathrm{MHz}$, respectively. The flow cell was washed with ultrapure degassed water, and the solution was then exchanged for SLB buffer ( $50 \mathrm{mM}$ Tris buffer, $\mathrm{pH} 7.4,300 \mathrm{mM} \mathrm{KCl}$ ) until a stable frequency signal was observed. To form the SLB, the $0.1 \mathrm{mM}$ SUVs mixtures were injected onto the sensor chip in the presence of calcium ions $\left(5 \mathrm{mM} \mathrm{CaCl}_{2}\right)$ in the SLB buffer at a constant flow rate of $50 \mu \mathrm{L} / \mathrm{min}$. The vesicles adsorb to the sensor surface and the calcium enhances their rupture and SLB formation $[64,65]$. The sensor chip was then washed with binding buffer (50 mM Tris buffer, $\mathrm{pH} 7.4,250 \mathrm{mM} \mathrm{KCl}, 5 \mathrm{mM} \mathrm{MgCl}_{2}$ ) until a profile characteristic for SLB formation was acquired. Protein solutions containing increasing concentrations of DivIVA $_{C d}(0.25-3 \mu \mathrm{M})$ were added to the SLB surface at a constant flow rate of $30 \mu \mathrm{L} / \mathrm{min}$. After loading the sample, the binding was measured until a stable base line was obtained. Finally, the flow cells containing the adsorbed DivIVA ${ }_{C d}$ protein were rinsed with reaction buffer. Data were analysed and plotted using Microsoft Excel and GraphPad Prism 8.

\subsection{TIRF Microscopy and Image Analysis}

The sample chambers for TIRF microscopy were freshly prepared as published previously $[40,66]$. Briefly, the chambers were created by attaching a plastic ring made from a cut PCR reaction tube on an extensively cleaned glass cover slip using ultraviolet glue. The coverslips' cleaning procedure involved washing with Piranha solution (a 3:1 mixture of sulfuric acid and 30\% hydrogen peroxide) and plasma treatment (Diener Zepto plasma system). To form the supported lipid bilayer, $5 \mathrm{mM} \mathrm{SUV} \mathrm{stock} \mathrm{solutions} \mathrm{were} \mathrm{first} \mathrm{diluted} \mathrm{in}$ SLB buffer ( $50 \mathrm{mM}$ Tris- $\mathrm{HCl} \mathrm{pH} \mathrm{7.4,300} \mathrm{mM} \mathrm{KCl)} \mathrm{to} \mathrm{obtain} 1 \mathrm{mM}$ lipid solutions and $\mathrm{CaCl}_{2}$ was added to a final concentration of $3 \mathrm{mM}$. Then, $30 \mu \mathrm{L}$ of the lipid solution were added to each chamber and incubated for $1 \mathrm{~h}$ at laboratory temperature in the dark. Afterwards, $30 \mu \mathrm{L}$ of SLB buffer were added to each chamber to obtain a $60 \mu \mathrm{L}$ final volume. Chambers were washed $5 \times$ with $100 \mu \mathrm{L}$ of SLB buffer to eliminate non-fused vesicles and $5 \times$ with $100 \mu \mathrm{L}$ of binding buffer $\left(50 \mathrm{mM}\right.$ Tris- $\left.\mathrm{HCl} \mathrm{pH}=7.4,150 \mathrm{mM} \mathrm{KCl}, 5 \mathrm{mM} \mathrm{MgCl}_{2}\right)$ to exchange the buffer. For better illustration, the Jove protocol can be followed [40]. TIRF microscopy 
imaging was performed using a TIRF microscope iMic equipped with an image splitter (Andor Tucam) and two Ixon 897 cameras using $60 \times$ or $100 \times$ oil immersion objectives at $20^{\circ} \mathrm{C}$ operated by LA (Lifeaquisition) software, version: 6.2.1. The laser power was adjusted depending on the signal intensity.

Image processing and analysis were carried out with the Fiji image processing package [67]. To reduce the noise in the images, the Anisotropic Diffusion 2D plugin was used with the default settings. To determine the area of the fluorescent signal, the Particle Analysis built-in function was employed, with MaxEntropy or Triangle threshold algorithms. In all cases, the same threshold settings were applied to compare images before and after DivIVA $_{C d}$ addition in the respective sample. The Microsoft Excel Histogram function was used to calculate the area distribution with a Bin range from 0 to $4 \mu \mathrm{m}^{2}$, with $0.2 \mu \mathrm{m}^{2}$ steps. The data were analysed and plotted in GraphPad Prism 8.

For the FRAP experiments shown in Figure S4, circular ROI with $\sim 10 \mu \mathrm{m}$ diameter was photo-bleached at full laser power using a $488 \mathrm{~nm}$ laser for TF-CL and $561 \mathrm{~nm}$ laser for $\mathrm{Rh}-\mathrm{PE}$ with $2 \mathrm{~ms} / \mu \mathrm{m}^{2}$ dwell time. The recovery of fluorescence was monitored at lower laser power (up to $30 \%$ ) with a $50 \mathrm{~ms}$ exposure times and $5 \mathrm{~s}$ intervals. The changes in fluorescence intensities along the axis indicated in Figure S4 were measured in Fiji and plotted in GraphPad Prism 8.

\subsection{Homology Modelling}

The homology model of the DivIVA C. difficile N-terminal domain was constructed using its B. subtilis homologue (PDB code 2WUJ) [38] as a template. The homology model itself was created by Swiss-Model [68]. The stability of the model was tested in a 100-nslong simulation and its final configuration was used as the initial configuration for all simulations with membranes. The model was stable throughout the whole $100 \mathrm{~ns}$ trajectory, with its RMSD converging within the initial first nanoseconds and remaining stable until the end of the simulation.

\subsection{Molecular Dynamics (MD) Simulations}

All MD simulations were performed using GROMACS 5.1.2 [69], the CHARMM36 force-field [70], and the TIP3P water model [71]. All simulations were conducted at $309.15 \mathrm{~K}$ and 1 bar in a $150 \mathrm{mM}$ aqueous solution of $\mathrm{NaCl}$ at neutral $\mathrm{pH}$. Simulations were performed in the NPT ensemble with periodic boundary conditions. The system temperature was held constant with the Nosé-Hoover thermostat [72,73] with a time constant of 1 ps and the pressure was controlled using the Parrinello-Rahman barostat [74] with a coupling time of $5 \mathrm{ps}$ and a compressibility of $4.5 \times 10^{-5} \mathrm{bar}^{-1}$. The solute and solvent were coupled to separate thermostats. Isotropic pressure coupling was applied in simulations with fully solvated protein. In systems with membranes, semi-isotropic coupling was used with the pressure normal to the membrane within the membrane plane coupled separately. Centre of mass movement was removed separately for the solvent and membrane with protein every 5 ps. Long-range electrostatics were modelled with PME $[75,76]$ with a direct space cut-off of $1.2 \mathrm{~nm}$. Short-range van der Walls interactions were cut-off at $1.2 \mathrm{~nm}$ with a force-shift applied from $1.0 \mathrm{~nm}$. All hydrogen atoms bound to heavy atoms were constrained with LINCS [77]. The equations of motion were integrated using a leap-frog integrator with a Verlet neighbour search using a $0.005 \mathrm{~kJ} \mathrm{~mol}^{-1} \mathrm{ps}^{-1}$ buffer.

\subsubsection{System Preparation for MD Simulations}

Membrane configurations were prepared with the CHARMM-GUI [78-81]. All membranes were solvated in a $150 \mathrm{mM}$ aqueous solution of $\mathrm{NaCl}$ with additional ions to neutralize the system. Membranes were equilibrated until the area-per-lipid (APL) converged to steady state (roughly $50 \mathrm{~ns}$ ). We investigated the interactions between the DivIVA $_{C d} \mathrm{~N}$-terminal domain and lipid membranes containing dioleoyl phosphatidylcholine (DOPC), dioleoyl phosphatidylglycerol (DOPG), and tetraoleylcardiolipin with a -2 e charge (TOCL2). Three different lipid compositions were considered: pure DOPC, 
a DOPC-DOPG-TOCL2 mixture with a mol ratio of 13:6:1, and a second mixture with a ratio of 11:4:3. These correspond to 65\% DOPC:30\% DOPG:5\% TOCL and 55\% DOPC:30\% DOPG:15\% TOCL, respectively. Each system consisted of 320 lipids equally distributed in each leaflet. The initial configurations of the membrane-protein simulations were generated by adding the homology model of the $\mathrm{N}$-terminal domain to the proximity of the equilibrated membrane with no solvent. The N-terminal domain was positioned with the domain tip (residues 14-18) facing the membrane. This orientation was chosen based on the reported preference of these loop residues for interacting with the membrane [38]. This membrane and domain system was subsequently solvated with an explicit water solution of $150 \mathrm{mM} \mathrm{NaCl}$. The excess charge of the system was neutralized with additional ions. The systems were then equilibrated for $100 \mathrm{~ns}$ followed by 200-ns-long simulations during which the protein-membrane interactions were sampled and evaluated. Each membrane composition was simulated in two replicas, which differed in the initial membrane configuration to obtain independent sampling [82].

\subsubsection{The Domain Orientation}

The orientation of the domain with respect to the membrane was calculated using the orthonormal vectors within the domain. We used the same definition as previously [37] for consistency and easier comparison. The first vector was aligned with the long axis of the domain and was defined by the centre of mass of the $C_{\alpha}$ atoms of two Leu 16 residues and the centre of mass of two whole Leu 45 residues from both protein chains. The second vector captured the orientation of the two short helices on the domain sides and was defined between the backbone $\mathrm{N}$ atoms of the Ile 7 residues. The third perpendicular vector was defined between the backbone $\mathrm{N}$ atoms of the Ile 31 residues and described the orientation of the two long helices. In simulations where the domain dissociated from the membrane, we did not evaluate the orientation of the domain with respect to the membrane.

Supplementary Materials: The following are available online at https:/ /www.mdpi.com/article/10 $.3390 /$ ijms22158350/s1.

Author Contributions: Conceptualization, N.L.; methodology, N.L., N.B., M.L., R.V., M.J. and I.B.; software, N.L., R.V. and M.J.; validation, N.L., N.B., M.L., R.V. and M.J.; formal analysis, N.L., N.B., M.L., R.V. and M.J.; investigation, N.L., R.V. and M.J.; resources, N.L., N.B., M.L., R.V., M.J. and I.B.; data curation, N.L., N.B., M.L., R.V. and M.J.; writing-original draft preparation, N.L.; writingreview and editing, N.L., N.B., M.J., R.V., M.L. and I.B.; visualization, N.L. and M.J.; supervision, R.V., M.L. and I.B.; project administration, R.V., M.L. and I.B.; funding acquisition, N.L., R.V., M.L. and I.B. All authors have read and agreed to the published version of the manuscript.

Funding: This research was funded by EMBO short term fellowship No. 8193, VEGA Grant 2/0001/21 from the Slovak Academy of Sciences, a Grant from the Slovak Research and Development Agency under contract APVV-18-0104, the Czech Science Foundation Grant GA20-20152S, and ERC Starting Grant No. 679239 "Self-organization of the bacterial cell". This research was also supported by the Scientific Service Units (SSU) of IST-Austria through resources provided by the Bioimaging Facility (BIF) and the Life Science Facility (LSF). Additional support was obtained from CEITEC 2020 (LQ1601) project with financial contribution made by the Ministry of Education, Youths and Sports of the Czech Republic within special support paid from the National Programme for Sustainability II funds. Computational resources were provided by the CESNET LM2015042 and the CERIT Scientific Cloud LM2015085, provided under the programme "Projects of Large Research, Development, and Innovations Infrastructures". The computational resources were obtained from IT4 Innovations National Supercomputing Center LM2015070 project supported by MEYS CR from the Large Infrastructures for Research, Experimental Development and Innovations.

Institutional Review Board Statement: Not applicable.

Informed Consent Statement: Not applicable.

Data Availability Statement: The authors declare that the data supporting the findings of this study are available within the article and its Supplementary Materials. 
Acknowledgments: We thank Daniela Krajčíkova, Katarína Muchová, Zuzana Chromíkova and other members of Barák's laboratory for useful discussions, suggestions and help. Special thanks also to Emília Chovancová for technical support. We are grateful to Juraj Labaj for drawing the model and for help with graphics. Many thanks to all members of Loose's laboratory: Maria del Mar López, Paulo Caldas, Philipp Radler, and other members of the Loose's laboratory for sharing their knowledge of SLB preparation and TIRF experiment chambers, for sharing coverslips and for help with the TIRF microscope and data analysis. We also thank the members of the Dept. of Biochemistry of Biomembranes at the Institute of Animal Biochemistry and Genetics, CBs SAS for their help with preparing the lipid mixtures. We thank J. Bauer for critically reading the manuscript.

Conflicts of Interest: The authors declare no conflict of interest.

\section{References}

1. Zhu, D.; Sorg, J.A.; Sun, X. Clostridioides difficile biology: Sporulation, germination, and corresponding therapies for C. difficile infection. Front. Cell. Infect. Microbiol. 2018, 8, 1-10. [CrossRef] [PubMed]

2. Guh, A.Y.; Mu, Y.; Winston, L.G.; Johnston, H.; Olson, D.; Farley, M.M.; Wilson, L.E.; Holzbauer, S.M.; Phipps, E.C.; Dumyati, G.K.; et al. Trends in U.S. burden of Clostridioides difficile infection and outcomes. N. Engl. J. Med. 2020, 382, 1320-1330. [CrossRef]

3. Marra, A.R.; Perencevich, E.N.; Nelson, R.E.; Samore, M.; Khader, K.; Chiang, H.Y.; Chorazy, M.L.; Herwaldt, L.A.; Diekema, D.J.; Kuxhausen, M.F.; et al. Incidence and outcomes associated with Clostridium difficile infections: A systematic review and meta-analysis. JAMA Netw. Open 2020, 3, e1917597. [CrossRef]

4. Rhea, S.; Jones, K.; Endres-Dighe, S.; Munoz, B.; Weber, D.J.; Hilscher, R.; MacFarquhar, J.; Sickbert-Bennett, E.; DiBiase, L.; Marx, A.; et al. Modeling inpatient and outpatient antibiotic stewardship interventions to reduce the burden of Clostridioides difficile infection in a regional healthcare network. PLOS ONE 2020, 15, e0234031. [CrossRef]

5. Lessa, F.C.; Gould, C.V.; Clifford McDonald, L. Current status of Clostridium difficile infection epidemiology. Clin. Infect. Dis. 2012, 55, 65-70. [CrossRef]

6. $\quad$ Lessa, F.C.; Mu, Y.; Bamberg, W.M.; Beldavs, Z.G.; Dumyati, G.K.; Dunn, J.R.; Farley, M.M.; Holzbauer, S.M.; Meek, J.I.; Phipps, E.C.; et al. Burden of Clostridium difficile Infection in the United States. N. Engl. J. Med. 2015, 372, 825-834. [CrossRef]

7. Gamba, P.; Veening, J.W.; Saunders, N.J.; Hamoen, L.W.; Daniel, R.A. Two-step assembly dynamics of the Bacillus subtilis divisome. J. Bacteriol. 2009, 191, 4186-4194. [CrossRef]

8. Mukherjee, A.; Dai, K.; Lutkenhaus, J. Escherichia coli cell division protein FtsZ is a guanine nucleotide binding protein. Proc. Natl. Acad. Sci. USA 1993, 90, 1053-1057. [CrossRef]

9. De Boer, P.; Crossley, R.; Rothfield, L. The essential bacterial cell-division protein FtsZ is a GTPase. Nature 1992, 359, $254-256$. [CrossRef]

10. Edwards, D.H.; Errington, J. The Bacillus subtilis DivIVA protein targets to the division septum and controls the site specificity of cell division. Mol. Microbiol. 1997, 24, 905-915. [CrossRef]

11. Eswaramoorthy, P.; Erb, M.L.; Gregory, J.A.; Silverman, J.; Pogliano, K.; Pogliano, J.; Ramamurthi, K.S. Cellular architecture mediates DivIVA ultrastructure and regulates Min activity in Bacillus subtilis. MBio 2011, 2, e00257-11. [CrossRef] [PubMed]

12. Marston, A.L.; Errington, J. Selection of the midcell division site in Bacillus subtilis through MinD-dependent polar localization and activation of MinC. Mol. Microbiol. 1999, 33, 84-96. [CrossRef] [PubMed]

13. Bramkamp, M.; Emmins, R.; Weston, L.; Donovan, C.; Daniel, R.A.; Errington, J. A novel component of the division-site selection system of Bacillus subtilis and a new mode of action for the division inhibitor MinCD. Mol. Microbiol. 2008, 70, 1556-1569. [CrossRef]

14. Bramkamp, M.; van Baarle, S. Division site selection in rod-shaped bacteria. Curr. Opin. Microbiol. 2009, 12, 683-688. [CrossRef]

15. Patrick, J.E.; Kearns, D.B. MinJ (YvjD) is a topological determinant of cell division in Bacillus subtilis. Mol. Microbiol. 2008, 70, 1166-1179. [CrossRef] [PubMed]

16. Hammond, L.R.; White, M.L.; Eswara, P.J. ¡vIVA la DivIVA! J. Bacteriol. 2019, 201, e00245-19. [CrossRef]

17. Migocki, M.D.; Freeman, M.K.; Wake, R.G.; Harry, E.J. The Min system is not required for precise placement of the midcell Z ring in Bacillus subtilis. EMBO Rep. 2002, 3, 1163-1167. [CrossRef]

18. Rodrigues, C.D.A.; Harry, E.J. The Min system and nucleoid occlusion are not required for identifying the division site in Bacillus subtilis but ensure its efficient utilization. PLoS Genet. 2012, 8, e1002561. [CrossRef]

19. Thomaides, H.B.; Freeman, M.; El Karoui, M.; Errington, J. Division site selection protein DivIVA of Bacillus subtilis has a second distinct function in chromosome segregation during sporulation. Genes Dev. 2001, 15, 1662-1673. [CrossRef]

20. Kaval, K.G.; Halbedel, S. Architecturally the same, but playing a different game: The diverse species-specific roles of DivIVA proteins. Virulence 2012, 3, 406-408. [CrossRef]

21. Dos Santos, V.T.; Bisson-Filho, A.W.; Gueiros-Filho, F.J. DivIVA-mediated polar localization of ComN, a posttranscriptional regulator of Bacillus subtilis. J. Bacteriol. 2012, 194, 3661-3669. [CrossRef] [PubMed]

22. Ben-Yehuda, S.; Rudner, D.Z.; Losick, R. RacA, a bacterial protein that anchors chromosomes to the cell poles. Science 2003, 299, 532-536. [CrossRef] [PubMed] 
23. Van Baarle, S.; Celik, I.N.; Kaval, K.G.; Bramkamp, M.; Hamoen, L.W.; Halbedel, S. Protein-protein interaction domains of Bacillus subtilis DivIVA. J. Bacteriol. 2013, 195, 1012-1021. [CrossRef]

24. Briley, K.; Prepiak, P.; Dias, M.J.; Hahn, J.; Dubnau, D. Maf acts downstream of ComGA to arrest cell division in competent cells of B. subtilis. Mol. Microbiol. 2011, 81, 23-39. [CrossRef]

25. Cha, J.H.; Stewart, G.C. The divIVA minicell locus of Bacillus subtilis. J. Bacteriol. 1997, 179, 1671-1683. [CrossRef] [PubMed]

26. Eswaramoorthy, P.; Winter, P.W.; Wawrzusin, P.; York, A.G.; Shroff, H.; Ramamurthi, K.S. Asymmetric division and differential gene expression during a bacterial developmental program requires DivIVA. PLoS Genet. 2014, 10, e1004526. [CrossRef]

27. Kang, C.M.; Nyayapathy, S.; Lee, J.Y.; Suh, J.W.; Husson, R.N. Wag31, a homologue of the cell division protein DivIVA, regulates growth, morphology and polar cell wall synthesis in mycobacteria. Microbiology 2008, 154, 725-735. [CrossRef]

28. Ramos, A.; Honrubia, M.P.; Valbuena, N.; Vaquera, J.; Mateos, L.M.; Gil, J.A. Involvement of DivIVA in the morphology of the rod-shaped actinomycete Brevibacterium lactofermentum. Microbiology 2003, 149, 3531-3542. [CrossRef]

29. Nguyen, L.; Scherr, N.; Gatfield, J.; Walburger, A.; Pieters, J.; Thompson, C.J. Antigen 84, an effector of pleiomorphism in Mycobactenum smegmatis. J. Bacteriol. 2007, 189, 7896-7910. [CrossRef]

30. Flärdh, K. Essential role of DivIVA in polar growth and morphogenesis in Streptomyces coelicolor A3(2). Mol. Microbiol. 2003, 49, 1523-1536. [CrossRef]

31. Makroczyová, J.; Jamroškovič, J.; Krascsenitsová, E.; Labajová, N.; Barák, I. Oscillating behavior of Clostridium difficile Min proteins in Bacillus subtilis. Microbiol. Open 2016, 5, 387-401. [CrossRef]

32. Rowlett, V.W.; Margolin, W. The bacterial Min system. Curr. Biol. 2013, 23, R553-R556. [CrossRef]

33. Jamroškovič, J.; Pavlendová, N.; Muchová, K.; Wilkinson, A.J.; Barák, I. An oscillating Min system in Bacillus subtilis influences asymmetrical septation during sporulation. Microbiology 2012, 158, 1972-1981. [CrossRef] [PubMed]

34. Valenčíková, R.; Krascsenitsová, E.; Labajová, N.; Makroczyová, J.; Barák, I. Clostridial DivIVA and MinD interact in the absence of MinJ. Anaerobe 2018, 50, 22-31. [CrossRef]

35. Lenarcic, R.; Halbedel, S.; Visser, L.; Shaw, M.; Wu, L.J.; Errington, J.; Marenduzzo, D.; Hamoen, L.W. Localisation of DivIVA by targeting to negatively curved membranes. EMBO J. 2009, 28, 2272-2282. [CrossRef] [PubMed]

36. Ramamurthi, K.S.; Losick, R. Negative membrane curvature as a cue for subcellular localization of a bacterial protein. Proc. Natl. Acad. Sci. USA 2009, 106, 13541-13545. [CrossRef] [PubMed]

37. Jurásek, M.; Flärdh, K.; Vácha, R. Effect of membrane composition on DivIVA-membrane interaction. Biochim. Biophys. Acta BBA Biomembr. 2019, 1862, 183144. [CrossRef] [PubMed]

38. Oliva, M.; Halbedel, S.; Freund, S.M.; Dutow, P.; Leonard, T.A.; Veprintsev, D.B.; Hamoen, L.W.; Löwe, J. Features critical for membrane binding revealed by DivIVA crystal structure. EMBO J. 2010, 29, 1988-2001. [CrossRef]

39. Vecchiarelli, A.G.; Li, M.; Mizuuchi, M.; Mizuuchi, K. Differential affinities of MinD and MinE to anionic phospholipid influence Min patterning dynamics in vitro. Mol. Microbiol. 2014, 93, 453-463. [CrossRef]

40. Ramm, B.; Glock, P.; Schwille, P. In vitro reconstitution of self-organizing protein patterns on supported lipid bilayers. J. Vis. Exp. 2018, 2018, 1-13. [CrossRef]

41. Guan, Z.; Katzianerb, D.; Zhub, J.; Goldfine, H. Clostridium difficile contains plasmalogen species of phospholipids and glycolipids. Biochim. Biophys. Acta 2014, 1842, 1353-1359. [CrossRef] [PubMed]

42. Reviakine, I.; Johannsmann, D.; Richter, R.P. Hearing what you cannot see and visualizing what you hear: Interpreting quartz crystal microbalance data from solvated interfaces. Anal. Chem. 2011, 83, 8838-8848. [CrossRef] [PubMed]

43. Dixon, M.C. Quartz crystal microbalance with dissipation monitoring: Enabling real-time characterization of biological materials and their interactions. J. Biomol. Tech. 2008, 19, 151-158. [PubMed]

44. De Kerchove, A.J.; Elimelech, M. Structural growth and viscoelastic properties of adsorbed alginate layers in monovalent and divalent salts. Macromolecules 2006, 39, 6558-6564. [CrossRef]

45. Renner, L.D.; Weibel, D.B. MinD and MinE interact with anionic phospholipids and regulate division plane formation in Escherichia coli. J. Biol. Chem. 2012, 287, 38835-38844. [CrossRef]

46. Huang, X.; Bai, Q.; Hu, J.; Hou, D. A practical model of quartz crystal microbalance in actual applications. Sensors 2017, 17, 1785. [CrossRef]

47. Lozeau, L.D.; Rolle, M.W.; Camesano, T.A. A QCM-D study of the concentration- and time-dependent interactions of human LL37 with model mammalian lipid bilayers. Colloids Surf. B Biointerfaces 2018, 167, 229-238. [CrossRef] [PubMed]

48. Kachel, K.; Asuncion-Punzalan, E.; London, E. The location of fluorescence probes with charged groups in model membranes. Biochim. Biophys. Acta BBA Biomembr. 1998, 1374, 63-76. [CrossRef]

49. McMahon, H.T.; Boucrot, E. Membrane curvature at a glance. J. Cell Sci. 2015, 128, 1065-1070. [CrossRef] [PubMed]

50. Huang, K.C.; Ramamurthi, K.S. Macromolecules that prefer their membranes curvy: MicroReview. Mol. Microbiol. 2010, 76, 822-832. [CrossRef]

51. Beltrán-Heredia, E.; Tsai, F.C.; Salinas-Almaguer, S.; Cao, F.J.; Bassereau, P.; Monroy, F. Membrane curvature induces cardiolipin sorting. Commun. Biol. 2019, 2, 1-7. [CrossRef]

52. Kusaka, J.; Shuto, S.; Imai, Y.; Ishikawa, K.; Saito, T.; Natori, K.; Matsuoka, S.; Hara, H.; Matsumoto, K. Septal localization by membrane targeting sequences and a conserved sequence essential for activity at the COOH-terminus of Bacillus subtilis cardiolipin synthase. Res. Microbiol. 2016, 167, 202-214. [CrossRef] 
53. Kawai, F.; Shoda, M.; Harashima, R.; Sadaie, Y.; Hara, H.; Matsumoto, K. Cardiolipin domains in Bacillus subtilis Marburg membranes. J. Bacteriol. 2004, 186, 1475-1483. [CrossRef]

54. Mileykovskaya, E.; Dowhan, W. Visualization of phospholipid domains in Escherichia coli by using the cardiolipin-specific fluorescent dye 10-N-nonyl acridine orange. J. Bacteriol. 2000, 182, 1172-1175. [CrossRef] [PubMed]

55. Pogmore, A.; Seistrup, K.H.; Strahl, H. The Gram-positive model organism Bacillus subtilis does not form microscopically detectable cardiolipin-specific lipid domains Growth conditions. Microbiology 2018, 164, 475-482. [CrossRef] [PubMed]

56. Koppelman, C.M.; Den Blaauwen, T.; Duursma, M.C.; Heeren, R.M.A.; Nanninga, N. Escherichia coli minicell membranes are enriched in cardiolipin. J. Bacteriol. 2001, 183, 6144-6147. [CrossRef] [PubMed]

57. Kawai, F.; Hara, H.; Takamatsu, H.; Watabe, K.; Matsumoto, K. Cardiolipin enrichment in spore membranes and its involvement in germination of Bacillus subtilis Marburg. Genes Genet. Syst. 2006, 81, 69-76. [CrossRef]

58. Sambrook, J.; Green, M.R. Molecular Cloning: A Laboratory Manual, III; Cold Spring Harbor Press: Cold Spring Harbor, NY, USA, 2001; Volume 1.

59. Sambrook, J.; Fritsch, E.F.; Maniatis, T. Molecular Cloning: A Laboratory Manual; Cold Spring Harbor Press: Cold Spring Harbor, NY, USA, 1989.

60. Ausubel, F.M.; Brent, R.; Kingston, R.E.; Moore, D.D.; Seidman, J.G.; Smith, J.A.; Struhl, K. Current Protocols in Molecular Biology; John Wiley \& Sons Inc.: Hoboken, NJ, USA, 1988; Volume 1-2.

61. Bendezú, F.O.; De Boer, P.A.J. Conditional lethality, division defects, membrane involution, and endocytosis in mre and mrd shape mutants of Escherichia coli. J. Bacteriol. 2008, 190, 1792-1811. [CrossRef]

62. Stahlberg, H.; Kutejová, E.; Muchová, K.; Gregorini, M.; Lustig, A.; Müller, S.A.; Olivieri, V.; Engel, A.; Wilkinson, A.J.; Barák, I. Oligomeric structure of the Bacillus subtilis cell division protien DivIVA determined by transmission microscopy. Mol. Microbiol. 2004, 52, 1281-1290. [CrossRef]

63. Rodahl, M.; Höök, F.; Krozer, A.; Brzezinski, P.; Kasemo, B. Quartz crystal microbalance setup for frequency and Q-factor measurements in gaseous and liquid environments. Rev. Sci. Instrum. 1995, 66, 3924-3930. [CrossRef]

64. Keller, C.A.; Kasemo, B. Surface specific kinetics of lipid vesicle adsorption measured with a quartz crystal microbalance. Biophys. J. 1998, 75, 1397-1402. [CrossRef]

65. Richter, R.; Mukhopadhyay, A.; Brisson, A. Pathways of Lipid Vesicle Deposition on Solid Surfaces: A Combined QCM-D and AFM Study. Biophys. J. 2003, 85, 3035-3047. [CrossRef]

66. Loose, M.; Fischer-Friedrich, E.; Ries, J.; Kruse, K.; Schwille, P. Spatial regulators for bacterial cell division self-organize into surface waves in vitro. Science 2008, 320, 789-792. [CrossRef] [PubMed]

67. Schindelin, J.; Arganda-Carreras, I.; Frise, E.; Kaynig, V.; Longair, M.; Pietzsch, T.; Preibisch, S.; Rueden, C.; Saalfeld, S.; Schmid, B.; et al. Fiji: An open-source platform for biological-image analysis. Nat. Methods 2012, 9, 676-682. [CrossRef] [PubMed]

68. Biasini, M.; Bienert, S.; Waterhouse, A.; Arnold, K.; Studer, G.; Schmidt, T.; Kiefer, F.; Cassarino, T.G.; Bertoni, M.; Bordoli, L.; et al. SWISS-MODEL: Modelling protein tertiary and quaternary structure using evolutionary information. Nucleic Acids Res. 2014, 42, 252-258. [CrossRef]

69. Abraham, M.J.; Murtola, T.; Schulz, R.; Páll, S.; Smith, J.C.; Hess, B.; Lindah, E. Gromacs: High performance molecular simulations through multi-level parallelism from laptops to supercomputers. SoftwareX 2015, 1-2, 19-25. [CrossRef]

70. Best, R.B.; Zhu, X.; Shim, J.; Lopes, P.E.M.; Mittal, J.; Feig, M.; MacKerell, A.D. Optimization of the additive CHARMM all-atom protein force field targeting improved sampling of the backbone $\varphi, \psi$ and side-chain $\chi 1$ and $\chi 2$ Dihedral Angles. J. Chem. Theory Comput. 2012, 8, 3257-3273. [CrossRef]

71. Jorgensen, W.L.; Chandrasekhar, J.; Madura, J.D.; Impey, R.W.; Klein, M.L. Comparison of simple potential functions for simulating liquid water. J. Chem. Phys. 1983, 79, 926-935. [CrossRef]

72. Nosé, S. A molecular dynamics method for simulations in the canonical ensemble. Mol. Phys. 1983, 52, 255-268. [CrossRef]

73. Hoover, W.G. Canonical dynamics: Equilibrium phase-space distributions. Phys. Rev. A 1985, 31, 1695. [CrossRef] [PubMed]

74. Parrinello, M.; Rahman, A. Polymorphic transitions in single crystals: A new molecular dynamics method. J. Appl. Phys. 1981, 52, 7182-7190. [CrossRef]

75. Darden, T.; York, D.; Pedersen, L. Particle mesh Ewald: An N·log(N) method for Ewald sums in large systems. J. Chem. Phys. 1993, 98, 10089-10092. [CrossRef]

76. Essmann, U.; Perera, L.; Berkowitz, M.L.; Darden, T.; Lee, H.; Pedersen, L.G. A smooth particle mesh Ewald method. J. Chem. Phys. 1995, 103, 8577-8593. [CrossRef]

77. Hess, B.; Bekker, H.; Berendsen, H.J.C.; Fraaije, J.G.E.M. LINCS: A Linear Constraint Solver for molecular simulations. J. Comput. Chem. 1997, 18, 1463-1472. [CrossRef]

78. Jo, S.; Lim, J.B.; Klauda, J.B.; Im, W. CHARMM-GUI membrane builder for mixed bilayers and its application to yeast membranes. Biophys. J. 2009, 97, 50-58. [CrossRef] [PubMed]

79. Wu, E.L.; Cheng, X.; Jo, S.; Rui, H.; Song, K.C.; Dávila-Contreras, E.M.; Qi, Y.; Lee, J.; Monje-Galvan, V.; Venable, R.M.; et al. CHARMM-GUI membrane builder toward realistic biological membrane simulations. J. Comput. Chem. 2014, 35, 1997-2004. [CrossRef]

80. Lee, J.; Cheng, X.; Swails, J.M.; Yeom, M.S.; Eastman, P.K.; Lemkul, J.A.; Wei, S.; Buckner, J.; Jeong, J.C.; Qi, Y.; et al. CHARMM-GUI input generator for NAMD, GROMACS, AMBER, OpenMM, and CHARMM/OpenMM simulations using the CHARMM36 additive force field. J. Chem. Theory Comput. 2016, 12, 405-413. [CrossRef] 
81. Jo, S.; Kim, T.; Iyer, V.; Im, W. CHARMM-GUI: A web-based graphical user interface for CHARMM. J. Comput. Chem. 2008, 29, 1859-1865. [CrossRef]

82. Grossfield, A.; Feller, S.E.; Pitman, M.C. Convergence of molecular dynamics simulations of membrane proteins. Proteins Struct. Funct. Genet. 2007, 67, 31-40. [CrossRef] 